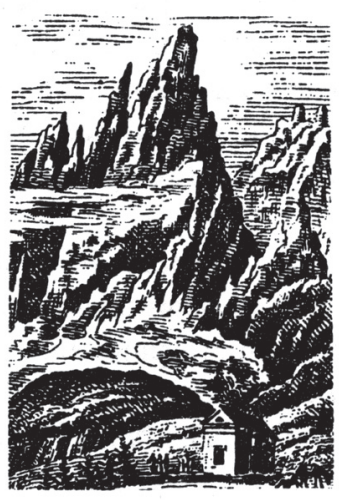

\author{
Jerzy Kapłon \\ ORCID: 0000-0002-4809-9148 \\ Centralny Ośrodek Turystyki Górskiej PTTK \\ jerzy.kaplon@cotg.pttk.pl
}

DOI: $10.19195 / 2084-4107.12 .15$

\title{
Karpackie Towarzystwo Narciarzy we Lwowie
}

Słowa-klucze: narciarstwo, historia turystyki, Karpackie Towarzystwo Narciarzy, Polski Związek Narciarski

Keywords: skiing, history of tourism, Carpathian Skiing Society, Polish Skiing Association

\section{The Carpathian Skiing Society in Lviv}

\section{Summary}

Very few people interested in the history of Polish skiing realise that it began in the second half of the 19th century in Galicia. It was first in the Eastern Carpathians that skis began to be used by foresters wanting to move more easily in their work and slightly later by tourists in their highland treks. In the late 19th century skiers appeared in Lviv, where in the early 20th century the sport began to be promoted by the Popular Entertainment Society. This was also where various institutions dealing with skiing were established, institutions like the Skiing Section of the Czarni Sports Club and, above all, the Carpathian Skiing Society (founded in early 1907), the first Polish association seeking to popularise skiing as its main objective. The society's founders included Kazimierz Panek, Maksymilian Dudryk, Zygmunt Klemensiewicz, Roman Kordys and Eugeniusz Romer, i.e. well-known mountaineers, tourists or even skiers. In addition to popularising skiing, 
e.g. by conducting training courses and publishing various manuals, the Society soon brought about a construction of a hostel in Sławsko. The resort became a favourite among Lviv skiers because of the excellent skiing conditions and good railway connection to Lviv. Burned during the war in May 1915, it was quickly rebuilt after the war and faithfully served tourists throughout the interwar period. On the day of its reopening, 11 March 1923, the Polish Skiing Association organised the 4th Polish Skiing Championship in Sławsko. By establishing its regional branches, the Carpathian Skiing Society promoted tourism in the Carpathians, initially in Galicia, and then throughout the Carpathian region in the Second Polish Republic. Kraków was the seat of a branch of the Society, which gave rise to another association, another important contributor to the development of Polish skiing — the Tatra Skiing Society. In 1919 the two organisations, together with three others, founded the Polish Skiing Association. Initially, the Society was active both in sport and tourism; later, given the easier access to Alps-type mountains with better snow conditions (the Tatras) for skiers from Zakopane, skiers from the region achieved much better results than their Lviv counterparts. The most important sporting achievements that should be noted include the successes of Janina Loteczkowa, who for several years in the second half of the 1920s had no equals in Europe. The Society was represented at the St. Moritz Olympics by Franciszek Kawa. In addition, the Society was instrumental in the construction of a professional ski jumping hill in Lviv. The 1930s were marked by a clear turn towards tourism, resulting in the construction and opening, in 1936, of a mountain hostel on Maryszewska. It is worth stressing, therefore, that such a relatively small organisation (its membership never exceeded 400 in one year) could do so much for the development of skiing in Poland.

Narciarstwo polskie powstało i rozwinęło się pod koniec XIX wieku w Karpatach Wschodnich, na obszarach będących w owym czasie na terenie Galicji (ziem polskich, które w wyniku dokonania rozbioru I Rzeczypospolitej stały się częścią Monarchii Austriackiej). Tam w drugiej połowie XIX wieku wielu turystów i pracowników leśnych rozpoczęło turystyczne i użytkowe wędrowanie na nartach. Pierwszy początki narciarstwa polskiego opisał Roman Kordys, który w 1910 roku w warszawskim dwutygodniku „Ruch”, w artykule Zarys rozwoju narciarstwa polskiego opisał przyczyny i warunki jego rozwojuํ. Pokaźniejszą pozycją wydawniczą zajmującą się historią narciarstwa był tom pierwszy „Roczników Polskiego Związku Narciarskiego" - pracy zbiorowej pod redakcją Stanisława Fächera, zatytułowanej Narciarstwo polskie ${ }^{2}$. Wątki takie zawierały też między innymi artykuły: Mariana Małaczyńskiego Nartami na Chomiak i Hower$l e^{3}$, w którym opisał wyprawę w Gorgany i Czarnohorę, czy Mariusza Zaruskiego Zarys rozwoju narciarstwa i zimowej turystyki polskiej w Tatrach ${ }^{4}$. Po II wojnie światowej ukazały się ponadto dzieła opisujące początki narciarstwa autorstwa Zenobiusza Pręgowskiego, przygotowane przez Wydawnictwo PTTK Kraj: Złota

1 Kolejne części artykułu w: R. Kordys, Zarys rozwoju narciarstwa polskiego, „Ruch” 1910, nr 2 (92), s. 17-21; 1910, nr 3 (93), s. 30-32; 1910, nr 4 (94), s. 43-47; 1910, nr 5 (95), s. 55-58; 1910, nr 6 (96), s. 68-70.

2 „Roczniki Polskiego Związku Narciarskiego” 1-3. Narciarstwo polskie, red. S. Fächer et al., Kraków 1925-1929 (dalej jako: Narciarstwo polskie).

3 M. Małaczyński, Nartami na Chomiak i Howerle, ,Pamiętnik Towarzystwa Tatrzańskiego” 18, 1897, s. 101-105.

${ }^{4}$ M. Zaruski, Zarys rozwoju narciarstwa i zimowej turystyki polskiej w Tatrach, „Pamiętnik Towarzystwa Tatrzańskiego" 34, 1913, s. 70-75. 
ksiegga narciarstwa polskiego i Dzieje narciarstwa polskiego ${ }^{6}$. Informacje o tej tematyce pojawiły się także w opracowaniach zbiorowych: 100 lat narciarstwa w Polsce - historia SN PTT, 1907 Zakopane $^{7}$, Narciarstwo polskie 1888-20088, Sporty zimowe w tradycji polskiej kultury fizycznej ${ }^{9}$. Karpackie Towarzystwo Narciarzy doczekało się ponadto artykułu w „Wierchach” w 1997 roku $^{10}$ oraz wydanym w 2016 roku przez Uniwersytet w Iwano-Frankiwsku roczniku „Karpaty”11; schroniskom KTN poświęcony był natomiast artykuł Schroniska Karpackiego Towarzystwa Narciarzy, który ukazał się po sympozjum w 120. rocznicę budowy pierwszego schroniska Towarzystwa Tatrzańskiego, które odbyło się w Krakowie w 1994 roku $^{12}$. Szerszy wykaz literatury poświęconej tej tematyce, a także pełniejszy opis dziejów Karpackiego Towarzystwa Narciarzy znajduje się w wydanej w 2018 roku przez Oficynę PTTK „Wierchy” pozycji Początki narciarstwa polskiego - Karpackie Towarzystwo Narciarzy we Lwowie 1907-1939 opracowanej przez autora niniejszego artykułu.

We Lwowie narciarze pojawili się na przełomie lat 1892 i 1893 - Kazimierz Hemerling przywiózł tu wówczas zakupione w Wiedniu narty. Według przywiezionego wzoru wykonano tu kilka ich par, które następnie Hemerling, Juliusz Calderoni, Kazimierz Borkowski, doktor Drohojowski oraz Kossak i Kuschėe (imiona trzech ostatnich nie są znane) wypróbowali na początku 1893 roku w Parku Stryjskim do zjazdu i biegu. Próby te ci sami entuzjaści (w różnym składzie personalnym) ponawiali kilkakrotnie, również na terenach przygotowanych na Wystawę Krajową, która odbyła się we Lwowie w 1894 roku $^{13}$.

Pierwsze działania mające na celu popularyzację narciarstwa rozpoczęto we Lwowie, w Towarzystwie Zabaw Ruchowych ${ }^{14}$ (powstało w grudniu 1904 roku $^{15}$ pod nazwą Towarzystwo Zabaw Ludu i Młodzieży, a w lutym 1906 roku przyjęło nazwą Towarzystwo Zabaw Ruchowych ${ }^{16}$ ) oraz w powołanym z inicjatywy Tadeusza Smoluchowskiego na przełomie lat 1905/1906 w Wolance (okolice Borysławia) Wolanieckim Klubie Narciarsko-Tenisowym, który stał się kołem powstałego Karpackiego Towarzystwa Narciarzy.

5 Zlota księga narciarstwa polskiego. Karpaty Wschodnie, oprac. Z. Pręgowski, Warszawa 1992.

6 Z. Pręgowski, Dzieje narciarstwa polskiego do 1914 roku, Warszawa 1994.

7 P. Dudzik, W. Szatkowski, Historia narciarstwa polskiego, [w:] 100 lat narciarstwa w Polsce - historia SN PTT, 1907 Zakopane, red. P. Dudzik, W. Szatkowski, Zakopane 2007, s. 9-19.

8 Narciarstwo polskie 1888-2008, red. L. Rak, E. Małolepszy, Jasło 2009.

9 Sporty zimowe w tradycji polskiej kultury fizycznej, red. L. Rak, Częstochowa 2011.

10 J. Kapłon, Karpackie Towarzystwo Narciarzy. Zarys dziejów, „Wierchy”63, 1997, s. 143-162.

11 J. Kapłon, Karpackie Towarzystwo Narciarzy — zarys dziejów, „Карпати. Людина, Етнос, Цивілізація" 6, 2016, s. 214-236.

12 J. Kapłon, Schroniska Karpackiego Towarzystwa Narciarzy, [w:] Materiaty z sympozjum w 120 rocznicę budowy pierwszego schroniska Towarzystwa Tatrzańskiego, Kraków 1994, s. 39-52.

13 Z zaczątków narciarstwa we Lwowie, „Sport” 1926, nr 170, s. 43.

14 R. Kordys, Poczatki polskiego narciarstwa, [w:] Narciarstwo polskie, s. 25-26.

15 Walne zgromadzenie Tow. Zabaw Ludu i Młodzieży, ,Słowo Polskie” 7.02.1906, nr 62, s. 5.

16 Sprawozdanie KTN za lata 1935/36, Lwów 1936, s. 9. 
Niebawem za konieczne uznano zgromadzenie w jednej organizacji zainteresowanych uprawianiem narciarstwa, co doprowadziło do powstania Karpackiego Towarzystwa Narciarzy. Zebranie założycielskie odbyło się 29 stycznia 1907 roku we Lwowie. O zamiarze spotkania poinformował dziennik „Słowo Polskie”, w którym w notatce zatytułowanej Sport zimowy pojawiło się następujące zaproszenie: „celem zorganizowania »Lwowskiego klubu narciarzy« zaprasza komitet wszystkich zwolenników sportu narciarskiego i innych sportów zimowych na wtorek 29 bm. o godz. 7 wieczór do kawiarni Schneidra" "17. Wśród uczestników spotkania było wielu znanych w owym czasie narciarzy, turystów i taterników, jak: Kazimierz Panek, Maksymilian Dudryk, Zygmunt Klemensiewicz, Roman Kordys, Eugeniusz Romer, Witold Wolański czy Tadeusz Wilusz, któremu przypisuje się zaproponowanie koniec końców przyjętej nazwy stowarzyszenia ${ }^{18}$.

Pierwszym prezesem Towarzystwa został Panek (był nim w okresie 1907/1908 i 1908/1909), będący jednocześnie prezesem Sekcji Turystycznej Towarzystwa Tatrzańskiego ${ }^{19}$, jego zastępcą został dr Tadeusz Kossowicz, Kordysowi powierzono funkcję sekretarza, Dudrykowi i Ludwikowi Pręgowskiemu - funkcję przodowników, a członkami wydziału zostali: Wilusz, Wolański oraz Tadeusz Pogórski i Stefan Dąbrowski. Ustalono, że statut stowarzyszenia zostanie opracowany przez Kordysa i wpierający go zespół, a następnie przedłożony do Namiestnictwa w celu zatwierdzenia ${ }^{20}$. Pismem do rzeczonego Namiestnictwa we Lwowie z dnia 11 lutego 1907 roku Kossowicz, Dudryk, Kordys, Pręgowski, Wilusz, Wolański i Mieczysław Lerski zgłosili założenie Karpackiego Towarzystwa Narciarzy. To właśnie te osoby, które dodatkowo podpisały załączony do korespondencji statut autorstwa Kordysa, należy uznać za założycieli Karpackiego Towarzystwa Narciarzy.

W pierwszym paragrafie statutu stwierdzono, że siedzibą stowarzyszenia jest Lwów, a językiem urzędowym — język polski. Za najważniejsze zadanie uznano budzenie i pielęgnowanie sportu narciarskiego ${ }^{21}$. W aktach c.k. Namiestnictwa we Lwowie znajdujemy informację, że opierając się na tym wystąpieniu, 16 lutego 1907 roku pod sygnaturą L. 20354 wpisano Karpackie Towarzystwo Narciarzy w katastrze stowarzyszeń (na stronie 401 pod pozycją 338), z informacją, że c.k. Namiestnictwo nie zabroniło zawiązania stowarzyszenia ${ }^{22}$. Zgodnie z obowiązującą w owym czasie Ustawą z 15 listopada 1867 roku o prawie do stowarzyszania

17 Wiadomości bieżace. Sport zimowy, „Słowo Polskie” 28.01.1907, nr 47, s. 6.

18 Karpackie Towarzystwo Narciarzy, „Sport” 1927, nr 200, s. 2.

19 Sprawozdanie Karpackiego Towarzystwa Narciarzy za czas od 1 listopada 1909 do 31 października 1910, Lwów 1910, s. 11.

20 Karpackie Towarzystwo Narciarzy, „Słowo Polskie” 30.01.1907, nr 51, s. 7.

21 Statut Karpackiego Towarzystwa Narciarzy, Прохання засновників товариства лижників у Львові про затвердження доданого статуту і рішення по цьому питанню ЦДІА України, м. Львів, Ф. 146, Оп. 58, Спр. 2926.

22 Pismo z dnia 11 lutego 1907 roku do Namiestnictwa we Lwowie, Прохання засновників товариства лижників у Львові про затвердження доданого статуту і рішення по цьому питанню, ЦДІА України, м. Львів, Ф. 146, Оп. 58, Спр. 2926. 
się (Dz.U. Nr 134) datę zgłoszenia woli powołania stowarzyszenia, a 11 lutego 1907 roku, należy uznać za datę powołania KTN²3.

Towarzystwo równolegle do działań turystycznych prowadziło działalność sportową i popularyzatorską. Szczegóły wielu wypraw członków KTN zawiera Złota księga narciarstwa polskiego opracowana przez Pręgowskiego ${ }^{24}$; skarbnicą wiedzy na ten temat są także odręcznie spisane przez Dudryka sprawozdania KTN z wypraw za okres od 1899 roku 28 lutego 1908 roku $^{25}$ oraz zachowane księgi wyjść klubowych za lata 1907-1911, znajdujące się w posiadaniu autora ${ }^{26}$.

W styczniu 1908 roku wydano broszurę Narty i ich użycie autorstwa Kordy$\mathrm{sa}^{27}$, a już 19 stycznia tego samego roku w Sławsku odbyły się pierwsze zorganizowane przez polskie stowarzyszenie na ziemiach polskich zawody narciarskie. Obejmowały bieg płaski na 100 i na 1500 metrów oraz zjazdowy też na 1500 metrów. Zorganizowała je Sekcja Narciarska Czarnych Lwów ${ }^{28}$. Biorąc pod uwagę działalność Towarzystwa Zabaw Ruchowych i Sekcji Narciarskiej Czarni Lwów, a także to, że w mieście powstało Karpackie Towarzystwo Narciarzy, pierwsze stowarzyszenie na ziemiach polskich zajmujące się narciarstwem, a pierwsze większe zawody w Tatrach zostały zorganizowane 28 marca 1910 roku przez Krakowskie Koło KTN, trudno nie zauważyć, że to w gronie lwowskich i pochodzących z Kresów turystów rodziło się polskie narciarstwo.

Już w kolejnym miesiącu — 28 lutego 1908 roku — Karpackie Towarzystwo Narciarzy złożyło do zatwierdzenia do Namiestnictwa we Lwowie nieco zmieniony statut, który został przyjęty 14 marca tegoż roku. Uznano, że możliwe jest tworzenie kół oraz określono zasady ich funkcjonowania. Nieco wcześniej, 18 lutego 1908 roku, „Słowo Polskie” doniosło o powstaniu Koła KTN w Przemyślu (ze Zdzisławem Rittersschildem na czele) ${ }^{29}$. Koniec roku również był pełen wydarzeń: 3 grudnia 1908 roku w Sali Sokoła we Lwowie odbyło się walne zgromadzenie KTN — prezesem wybrano Panka ${ }^{30}$; 4 grudnia 1908 roku powstało Koło Karpackiego Towarzystwa Narciarzy w Krakowie ${ }^{31}$, jak donosiło „Słowo Polskie”

23 Pismo c.k. Dyrekcji Policji we Lwowie z dnia 19 lutego 1907 roku, Державний архів Львівської області (ДАЛО), Справа про діяльність товариства “Карпатське товариство лижників у Львоbа, Ф. 110, Оп. 4, Cnp. 13, k. 2.

24 Zlota księga..., s. 129-136.

${ }_{25}$ Sprawozdania Maksymiliana Dudryka z wypraw turystycznych za okres $1899 \mathrm{r}$. do 18 luty 1908 r., rękopis, zbiory prywatne Alicji i Jerzego Kapłonów.

26 Sprawozdania KTN z wypraw turystycznych za okres 25 grudnia 1907-22 kwietnia 1911, rękopis, zbiory prywatne Alicji i Jerzego Kapłonów.

27 Sprawozdanie Wydziału Karpackiego Towarzystwa Narciarzy za rok 1935/6, Lwów 1936, s. 7.

28 A. Fredro-Boniecki, Historja narciarstwa polskiego 1907-1914 r., [w:] Narciarstwo polskie, s. 56-58.

29 Z. Januszewski, Kronika Sportowa, „Słowo Polskie” 18.02.1908, nr 82, s. 9.

30 Z. Januszewski, [b.t.], „Słowo Polskie” 6.12.1908, nr 570, Muzeum Tatrzańskie, Spuścizna po Z. Pręgowskim, z. 1908 r., s. 3.

31 A. Bobkowski, Tatrzańskie Towarzystwo Narciarzy w Krakowie, [w:] O narciarstwie, Kraków 1912, s. 23; R. Kordys, Tatrzańskie Towarzystwo Narciarzy, „Wędrowiec” 2, 1912, nr 27, s. 522, 523; A. Zieliński, [inc.] Dnia 4 grudnia 1938..., [w:] Tatry, zestawił i wstępem zaopatrzył 
z dnia 19 lutego 1909 roku, w skład władz weszli: Jan Fischer — przewodniczący, prof. Karol Bobrzyński — zastępca, Walery Goetel — sekretarz, oraz Władysław Pawlica - przodownik narciarski, a także czterech innych członków zarządu.

Prowadzona przez Koło KTN w Krakowie działalność miała rozległy charakter. Organizowano akcję promocyjną: wieczory z pokazywaniem zdjęć i przeźroczy, wykłady, kursy, inspirowano artykuły dziennikarskie. Ponadto 13 lutego 1909 roku Pawlica na łąkach w Woli Justowskiej zorganizował kurs dla narciarzy z udziałem kilkunastu osób, Koło zajmowało się bowiem turystyką narciarską $\mathrm{i}$ to mającą pionierski charakter na polu jej popularyzacji w Beskidach. W dniach 19 i 20 lutego 1909 roku Goetel szkolił działaczy Oddziału „Beskid” Towarzystwa Tatrzańskiego z Nowego Sącza. Podczas szkolenia w Ptaszkowej wpierw odbył się pokaz przeźroczy obrazujących techniki narciarskie, w dalszej kolejności 20 osób (w tym pięć pań) odbyło szkolenie praktyczne ${ }^{32}$. Z kolei 6 lutego 1910 roku Koło wysłało reprezentację na zawody urządzane przez Wintersportklub na Magórce koło Bielska. Jak doniósł „Czas” z 9 lutego 1910 roku, zawody te, z udziałem ponad dwustu narciarzy z różnych krajów, w tym Niemiec, Austrii i Danii, zakończyły się sukcesem Polaków. Odbył się tam między innymi konkurs skoków, podczas którego oddawano skoki do 10,5 metra, bieg młodzieży szkolnej z udziałem 25 zawodników, bieg pań z udziałem sześciu zawodniczek (wygrany przez Polkę - Sabińską, imię nieznane) oraz pokaz technik zjazdowych wykonany przez reprezentantów KTN. Bieg główny, o długości 4,8 kilometra, wygrał Aleksander Bobkowski, czwarty był Pawlica, piąty — Goetel ${ }^{33}$.

Krakowskie Koło KTN 28 marca 1910 roku w Zakopanem zorganizowało I Międzynarodowy Dzień Narciarski ${ }^{34}$, uznany za pierwsze zawody w narciarstwie polskim na taką skalę. Odbyły się na Hali Goryczkowej, a liczba uczestników i widzów wynosiła 250 osób. Bieg w kategorii juniorów (1500 metrów przy różnicy wysokości 300 metrów) i slalom (3000 metrów przy różnicy wysokości 300 metrów) wygrał lwowianin Jan Jarzyna w czasie odpowiednio 1 minuta i 35 sekund oraz 4 minuty i 12 sekund. Był reprezentantem KTN i Czarnych Lwów ${ }^{35}$. Niebawem w Krakowskim Kole KTN zwyciężyły tendencje separatystyczne. Na dzień 10 października 1910 roku zapowiedziano walne zebranie Koła, na którym prócz przedstawienia sprawozdania z działalności zapowiedziano dyskusję nad zmianą statutu $^{36}$. Wedle notatki w „Nowej Reformie” zebranie to odbyło się 17 października ${ }^{37}$. W wyniku podjętych ustaleń Koło rozwiązano i powołano stowarzyszenie

A. Zieliński, Kraków 1938, s. 1 nlb. (wydawnictwo to opublikowane zostało w dwóch mutacjach, z których jedna nie zawiera powołanego tekstu).

32 F. Wzorek, M. Töpfer, Sprawozdanie Zarzadu Oddziału Tow. Tatrzańskiego „Beskid” w Nowym Saczu za rok 1909, „Pamiętnik Towarzystwa Tatrzańskiego” 31, 1910, s. XLVII.

33 Wyścigi narciarskie w Bielsku, „Czas” 63, 1910, nr 64, s. 2.

34 A. Bobkowski, op. cit., s. 27.

35 „,ski”, Dzień narciarski w Zakopanem, „Nasz Kraj” 5, 1910, nr 93, s. 9-10.

36 Zaproszenie na walne zebranie Krakowskiego Koła Karpackiego Tow. Narciarzy, Archiwum Muzeum Tatrzańskiego, sygn. AR/NO 234, k. 170.

37 Sport zimowy, „Nowa Reforma” 29, 1910, nr 475, s. 2. 
„Narta”38, które pod tą nazwą przetrwało zaledwie miesiąc i przekształciło się w Tatrzańskie Towarzystwo Narciarzy ${ }^{39}$.

Koło w Przemyślu zasadniczo nie prowadziło samodzielnej działalności, uczestnicząc w wyprawach KTN oraz prowadząc działania promujące narciarstwo - „Słowo Polskie” z 26 stycznia 1909 roku informowało, że Koło to urządziło w obecności licznych widzów pokaz wyświetlanych zdjęć z Tatr i innych pasm karpackich zrealizowany przez Kordysa. Po tej projekcji wykład na temat narciarstwa wygłosił prof. Bolesław Błażek, nauczyciel gimnazjalny ${ }^{40}$. Efektem takiej akcji propagandowej było zorganizowanie wyprawy na Trościan, zapowiedzianej w „Słowie Polskim” z 10 lutego 1909 roku. Wyprawa pod przewodnictwem Rittersschilda miała się odbyć z udziałem pań ${ }^{41}$. W 1913 roku Koło mogło pochwalić się 13 członkami, w tym sześcioma oficerami austriackimi.

Rozwój narciarstwa i uznanie przez działaczy KTN Sławska za miejscowość posiadającą szczególnie przychylną lokalizację wymagało stworzenia tam bazy noclegowej. W tym celu KTN wynajął w Sławsku w karczmie Rothfelda na sezon zimowy kilka łóżek dla swoich członków ${ }^{42}$.

Kolejne walne zgromadzenie KTN odbyło się 7 grudnia 1909 roku — Panek podziękował członkom KTN za współpracę podczas trzech lat pełnienia funkcji prezesa, wybrano też nowy zarząd, na którego czele stanął Tadeusz Smoluchowski.

Sportowe aspiracje KTN wykazywało od początku istnienia. Dało temu dowody nie tylko organizując zawody narciarskie, lecz także stając się wraz z Akademickim Klubem Turystycznym i innymi organizacjami sportowymi (Wisła Kraków, Czarni Lwów, Pogoń Lwów) założycielem krótko istniejącego Polskiego Związku Sportowego ${ }^{43}$. Przeprowadzone 5 lutego 1911 roku w Zakopanem zawody prócz KTN miały już kilku innych organizatorów (Tatrzańskie Towarzystwo Narciarzy, Sekcja Narciarska AZS, SN TT $)^{44}$. Na tych zawodach członkowie KTN zajęli najwyższe lokaty:

— bieg juniorów: pierwsze miejsce — Tadeusz Konicki;

— bieg akademicki: 1. miejsce - Stanisław Menda (równolegle zawodnik Czarnych Lwów), drugie miejsce - Józef Bizoń;

— bieg główny: pierwsze miejsce - Wodzisław Świtalski (równolegle zawodnik Czarnych Lwów), trzecie miejsce — Józef Bizoń ${ }^{45}$.

38 A. Bobkowski, op. cit., s. 30.

39 Więcej w J. Kapłon, Tatrzańskie Towarzystwo Narciarzy. Zarys dziejów, Kraków 2013.

40 „Słowo Polskie” 26.01.1909, nr 42, Muzeum Tatrzańskie, Spuścizna po Z. Pręgowskim, z. 1909 r., s. 125.

41 „Słowo Polskie” 10.02.1909, nr 67, Muzeum Tatrzańskie, Spuścizna po Z. Pręgowskim, z. 1909 r., s. 143.

42 „Słowo Polskie” 11.01.1909, nr 16, Muzeum Tatrzańskie, Spuścizna po Z. Pręgowskim, z. 1909 r., s. 81 .

43 Ztota ksiegga..., s. 244.

44 Sprawozdanie KTN za czas od 1 listopada 1910 do października 1911, Lwów 1911, s. 6.

45 A. Fredro-Boniecki, op. cit., s. 59. 
Towarzystwo nie było organizacją liczną, w 1910 roku składki w wysokości 5 koron opłaciło 78 osób, a w 1911 roku - 130. W sprawozdaniu za rok 1910 podano, że KTN liczy 168 członków $^{46}$, a przed wybuchem I wojny światowej KTN osiągnął liczbę 403 członków.

Naturalną konsekwencją prowadzenia intensywnej działalności wycieczkowej było dążenie do posiadania własnej bazy noclegowej w górach. Jak już wspomniano, wybór padł na Sławsko w Bieszczadach, w którym w 1908 roku wynajęto stałą kwaterę, a następnie - w 1910 roku rozpoczęto budowę schroniska. W międzyczasie - 10 sierpnia 1909 roku - Ministerstwo Robót Publicznych przyznało KTN dofinansowanie na ten cel w wysokości 10 tysięcy koron, płatne w ratach po 5 tysięcy w 1910 i 1911 roku $^{47}$. Ponadto w wyniku starań Kazimierza Lubienieckiego Sodalicja Mariańska Panów we Lwowie wsparła budowę schroniska pożyczką w wysokości 5 tysięcy koron ${ }^{48}$. Budowę prowadzili architekci ze Lwowa, członkowie KTN: Tadeusz Mokłowski i Józef Jankowski ${ }^{49}$. W lutym 1911 roku rozpoczęto działalność noclegową. Co ciekawe, zachowała się księga pamiątkowa schroniska - pierwszy wpis ma datę 21 lutego 1911 roku, ostatni przed zniszczeniem obiektu w czasie I wojny światowej - 29 kwietnia 1914 roku, a ostatni - 5 lutego 1922 roku.

W 1911 roku (dokładnie 15 lipca) została podpisana umowa z Michaliną Błażejowską, która została gospodarzem schroniska; następnie 6 stycznia 1912 roku superior zakonu jezuitów we Lwowie, ksiądz Stanisław Sopuch, poświęcił obiekt. W programie otwarcia były zawody narciarskie — w niedzielę 7 stycznia 1912 roku $^{50}$ rozegrano bieg otwarcia schroniska ze szczytu Trościana (1235 m n.p.m.) do schroniska. Bieg stał się imprezą coroczną. Podczas zawodów, pierwszy raz w Galicji, jak podaje „Czas” z 9 stycznia 1912 roku, zorganizowano konkurs narciarski w skokach; zwyciężył Józef Jawor, instruktor wojskowych oddziałów narciarskich, skokiem o długości 9,9 metra $^{51}$.

Położone w odległości 300 metrów od stacji kolejowej schronisko pozwalało na nocleg 44 osób. Kosztowało 15082 korony i 20 halerzy. Zadbano też o promocję, drukując tysiąc kart pocztowych z jego wizerunkiem. Niestety w maju 1915 roku schronisko zostało spalone przez wojska rosyjskie ${ }^{52}$.

46 Sprawozdanie KTN za czas od 1 listopada 1909 do 31 października 1910, Lwów 1910, spis członków zwyczajnych, s. 40-45.

${ }^{47}$ Potwierdzenie odbioru reskryptu c.k. Namiestnictwa z dnia 3 stycznia 1911 roku w sprawie asygnaty na kwotę 5000 K., Lwowskie starostwo grodzkie, Державний архів Львівської області (ДАЛО), Справа про діяльність товариства “Карпатське товариство лижників у Львоьа, Ф. 110, Оп. 4, Cnp. 13, k. 24.

48 Sprawozdanie KTN za czas od 1 listopada 1910..., s. 5.

49 Sprawozdanie KTN za czas od 1 listopada 1909 do 31 października 1910, Lwów 1910, s. 15.

50 Książka pamiątkowa schroniska w Sławsku za lata 1911-1924, zbiory prywatne Alicji i Jerzego Kapłonów, s. 31.

51 Wycinek z gazety, Archiwum Państwowe Kraków TTN 12/3, d. 205.

52 Schronisko narciarskie w Stawsku, „Wierchy” 1, 1923, s. 287. 
Latem 1921 roku, po uspokojeniu sytuacji politycznej związanej z wojnami Polski z Rosją i Ukrainą, przystąpiono do odbudowy. Obiekt usytuowano w miejscu starego i na Boże Narodzenie w 1922 roku udzielano już w nim noclegów; następnie 11 marca 1923 roku w południe ks. prof. Władysław Pokiziak poświęcił nowe schronisko ${ }^{53}$. W trakcie otwarcia odbyły się IV związkowe mistrzostwa Polski w narciarstwie. Schronisko miało $134 \mathrm{~m}^{2}$ powierzchni użytkowej i 56 miejsc noclegowych ${ }^{54}$, nadal prowadzone było przez Błażejowską i oferowało całodzienne wyżywienie. W czerwcu 1928 roku gospodarzem obiektu została niejaka pani Alber ${ }^{55}$, a od czerwca 1929 roku - Szczepan Witkowski ${ }^{56}$. Przed sezonem zimowym 1930 roku zakończono modernizację, która polegała na przedłużeniu budynku od strony wschodniej o 6 metrów na całej wysokości. W 1938 roku dzierżawcą obiektu został Roman Bielański ${ }^{57}$. Schronisko w Sławsku nadało nowe tory funkcjonowaniu miejscowości, która przekształciła się w znaną destynację letniskową. W maju 1995 roku obiekt miał się dobrze, choć był opuszczony ${ }^{58}$.

Troska o budowę i eksploatację schroniska nie przysłaniała zarządowi konieczności prowadzenia innych działań popularyzujących turystykę i sporty narciarskie. KTN 14 marca 1909 roku urządziło w Sławsku „Meeting sportów narciarskich" 59 . Zgodnie z opisem zawodów zawartym w księdze pamiątkowej odbyły się one w obecności około 80 osób (widzów i zawodników) w dwóch konkurencjach — zjazd narciarski i saneczkarski. Drogę do zjazdu narciarskiego oznaczono 12 chorągiewkami, ze startem pod szczytem Pliszki. Różnica wysokości między startem a metą zjazdu wynosiła 300 metrów, długość mierzona po terenie - około 1 kilometr, a meta mieściła się na dole nad potokiem. Do zjazdu zgłosiło się 27 zawodników, z których siedmioro nie było członkami KTN, wśród nich była jedna kobieta. Zjazd wygrał (z czasem 2 minuty 25 sekund) Bernard Rappaport, pierwsze miejsce (z czasem 2 minuty 50 sekund) zajął S. Menda, a trzecie (z czasem 2 minuty 57 sekund) - M. Dudryk ${ }^{60}$.

Pod koniec roku, 7 grudnia 1909 roku, we Lwowie odbyło się walne zgromadzenie KTN, podczas którego prezesem wybrano Smoluchowskiego ${ }^{61}$. Był nim

53 Książka pamiątkowa schroniska w Stawsku za lata 1911-1924..., s. 108.

54 Schronisko narciarskie w Stawsku, s. 287.

55 XXIII Sprawozdanie KTN za czas od 1 listopada 1928 roku do 31 października 1929, Lwów 1929, s. 15 .

56 XXIV Sprawozdanie KTN za czas od 1 listopada 1929 roku do 31 października 1930, Lwów 1930, s. 2.

57 Schroniska w Beskidzie Niskim i w Bieszczadach, Centralne Archiwum Turystyki Górskiej PTTK w Krakowie (dalej jako: CATG), sygn. 15.02.09.

58 J. Kapłon, Sprawozdanie z wizji lokalnej w Stawsku w maju 1995 roku, maszynopis w posiadaniu autora.

59 Sprawozdanie KTN za czas od 1 listopada 1909..., s. 14.

60 Księga wyjść narciarskich KTN za lata 1907-1910, zbiory prywatne Alicji i Jerzego Kapłonów, s. 113.

${ }^{61}$ Pismo KTN z dnia 9 grudnia 1909 roku do Dyrekcji c.k. Policji we Lwowie, Lwowskie starostwo grodzkie, Державний архів Львівської області (ДАЛО), Справа про діяльність товариства “Карпатське товариство лижників у Львоьа, Ф. 110, Оп. 4, Спр. 13, k. 15. 
przez następne trzy lata. Na kolejne, które odbyło się 22 grudnia 1910 roku w sali posiedzeń Towarzystwa Gimnastycznego „Sokół Macierz” we Lwowie przy ulicy Zimorowicza, pierwszy raz wydano drukiem sprawozdanie. Zawierało ono część sprawozdawczą, w której wydział (dzisiaj nazywany zarządem) zamieścił informację o działalności w okresie od 1 listopada 1909 do 31 października 1910 roku, a także artykuł, w którym przedstawiono historię powstania KTN, i wykaz wycieczek zimowych KTN w sezonie 1909/1910. W sali Skautów Towarzystwa Gimnastycznego „Sokół Macierz” we Lwowie 21 grudnia 1911 roku odbyło się kolejne walne zgromadzenie KTN. Informacje o działalności KTN realizowanej w trakcie roku sprawozdawczego znów zawarto w wydrukowanym sprawozdaniu $^{62}$. Wśród interesujących danych pojawia się zestawienie wycieczek zimowych zrealizowanych przez i dla członków KTN: na przełomie lat 1907/1908 urządzono 20 wycieczek z udziałem 141 osób, w sezonie 1908/1909 w 22 wycieczkach uczestniczyło 145 osób, w latach 1909/1910 było ich 28 z udziałem 202 osób, podczas gdy w opisywanym sezonie 1910/1911 w 62 wycieczkach wzięły udział 303 osoby. Niezależnie od tego w okolicy Lwowa urządzano bezpłatne kursy narciarskie. W okresie letnim w 1911 roku urządzono dziewięć wycieczek kolarskich z udziałem 69 osób oraz osiem wycieczek pieszych z udziałem 46 uczestników, w tym w skały Bubniszcza z treningiem wspinaczkowym ${ }^{63}$. Za okres sprawozdawczy 1910/1911 składkę wpłaciło 130 członków, czyli 52 osoby więcej niż w sezonie ubiegłym.

Pod koniec 1911 roku powstało Koło KTN w Wiedniu, założone przez pięciu studiujących tam członków KTN ${ }^{64}$. Między 23 stycznia a 1 lutego 1912 roku Towarzystwo gościło delegata Ministerstwa Robót Publicznych — Willego Rickmer Rickmersa, który wizytował schronisko w Sławsku oraz wziął udział w kilku wyprawach górskich. Dzięki niej we wrześniu 1912 roku KTN został przyjęty do Austriackiego Związku Narciarskiego ${ }^{65}$.

Swoją aktywność turystyczną działacze KTN przejawiali na rozmaitych polach. Zebrani 12 kwietnia 1912 roku we Lwowie w siedzibie Krajowego Związ$\mathrm{ku}$ Zdrojowisk i Uzdrowisk (KZZiU) przedstawiciele środowiska turystycznego podjęli decyzję o utworzeniu Sekcji Turystycznej tegoż Związku. Wśród członków Komisji Statutowej znaleźli się działacze KTN: Eugeniusz Romer, Aleksander Lisiewicz, Roman Kordys, Mieczysław Orłowicz, Tadeusz Smoluchowski i Zygmunt Klemensiewicz ${ }^{66}$. W wyniku tego 15 lutego 1913 roku, w czwartym roku wydawania periodyku KZZiU „Nasze Zdroje”, jako dodatek turystyczny do tego periodyku wydano czasopismo turystyczne i narciarskie pod tytułem „Nasza Tu-

62 Karpackie Towarzystwo Narciarzy, Sprawozdanie KTN za rok administracyjny 1911/12, Lwów 1912, s. 16.

63 Sprawozdanie KTN za czas od 1 listopada 1910..., s. 7.

${ }^{64}$ Sprawozdanie Wydziału KTN za rok administracyjny1911/12, Lwów 1912, s. 9.

65 Ibidem, s. 6.

66 Polskie Towarzystwo Krajoznawcze we Lwowie, „Nasze Zdroje” 3, 1912, nr 9, s. 143-144. 
rystyka". Dodatek ten pod redakcją dra Orłowicza został organem Sekcji Turystycznej KZZiU, KTN oraz Akademickiego Klubu Turystycznego ${ }^{67}$.

Rok 1912 KTN zakończył z 221 członkami. W tym czasie rozpoczęła się dyskusja na temat dualizmu w rozwoju narciarstwa, a mianowicie na temat pogłębiającego się rozdziału sportowego i turystycznego podejścia do niego. KTN opowiedziało się za równomiernym traktowaniu obydwu tych kierunków.

W kolejnym sezonie zimowym 1912/1913 KTN zrealizował ponad 20 wycieczek zbiorowych do Sławska i jedną na Czarnohorę, z udziałem średnio 20 uczestników. Ważnym elementem jednego z cyklicznych wyjazdowych szkoleń była wizyta znanego norweskiego trenera narciarskiego Wornera Werenskiölda. Szkolił on w Sławsku grupę 81 lwowian (w tym 14 pań) w dniach 25-29 grudnia 1912 roku. Udzielił lekcji i wyjaśnił zasady wykonywania skoków narciarskich ${ }^{68}$.

Kolejne walne zgromadzenie KTN odbyło się 13 grudnia 1912 roku, wybrano na nim zarząd Towarzystwa z nowym prezesem, którym został Kordys ${ }^{69}$. Już pod jego przewodnictwem 26 stycznia 1913 roku KTN zorganizował w Sławsku bieg rozstawny drużynowy na trasie o długości około 6 kilometrów, w którym wystąpiło pięć drużyn, a który wygrała I drużyna KTN w składzie: Leszek Pawłowski, Józef Kawecki, Maksymilian Dudryk, uzyskując czas 36 minut 54 sekund. Drugie miejsce zajęła drużyna SN AKT ${ }^{70}$.

W pierwszej połowie grudnia 1912 roku Koło w Wiedniu zrealizowało wyprawę w Wysokie Taury, Koło KTN w Samborze zdobyło Pikuj (1405 m n.p.m.) i wiele szczytów w Bieszczadach, podczas gdy Koło w Przemyślu zrealizowało liczne imprezy. Po otrzymaniu najwyższych laurów w rozpoczętej rywalizacji sportowej w roku 1912, rozpoczęta 21 marca 1913 roku wyprawa KTN dokonała zimowego przejścia granią Gorganów. W 1913 roku KTN utworzyło kolegium sędziowskie i komisję sportową, których zadaniem było czuwanie nad prawidłowym przebiegiem zawodów sportowych. W roku tym nadal prowadzono intensywną akcję propagandową, przeprowadzając 29 odczytów (przy czym interesujące jest, że KTN dysponowało wówczas 980 przeźroczami) oraz wydając dotowaną przez Ministerstwo Robót Publicznych oraz Krajowy Związek Turystyczny broszurę Zima i narty ${ }^{71}$. Liczba członków osiągnęła poziom 317 osób, z których 260 opłaciło składki. Na sezon 1912/1913 zarząd pozyskał dla swoich członków bazę noclegową w budynku Lwowskiego Zarządu Kolejowych Kolonii Wakacyjnych w Tuchli ${ }^{72}$.

W latach 1913 i 1914 zawodnicy KTN byli w czołówce większości krajowych zawodów sportowych. Podczas zawodów zorganizowanych 2 marca 1913 roku w Sławsku przez Sekcję Narciarską AKT zawodnicy KTN, mimo obecności czołówki narciarzy z Krakowa i Zakopanego, odnieśli liczne sukcesy. W biegu

\footnotetext{
67 „Nasza Turystyka” 1, 1913, nr 1, s. 1.

68 II. Karpackie Towarzystwo Narciarzy, „Nasza Turystyka” 1, 1913, nr 1, s. 2.

69 Sprawozdanie Wydziału KTN za rok administracyjny 1912/13, Lwów 1913, s. 26.

70 A. Fredro-Boniecki, op. cit., s. 60.

71 Sprawozdanie Wydziału KTN za rok 1912/13, s. 11.

72 Ibidem, s. 9.
} 
juniorów na trasie Ilza-Sławsko, w którym startowało dziewięciu zawodników, drugie miejsce zajął Zabawski. Natomiast w biegu seniorów na trasie Wełyki Werch-Sławsko, w którym startowało dziesięciu zawodników drugie miejsce zajął Kawecki. W zawodach w slalomie startowało również dziesięcioro zawodników, w tym jedna kobieta - Maria Biesiadzka, reprezentantka KTN. Zwyciężył L. Worosz z $\mathrm{KTN}^{73}$.

Bieg upamiętniający otwarcie schroniska w Sławsku, który odbył się 16 marca 1913 roku, na trasie 6 kilometrów wygrał Stefan Łuszczyński z KTN. Z kolei w zawodach odbywających się w dniach 23-25 marca 1913 roku, zorganizowanych przez TTN w Zakopanem, w biegu głównym trzecie miejsce zdobył Łuszczyński (KTN, Czarni Lwów), w slalomie drugie miejsce zajął reprezentujący KTN Leopold Worosz, a drużyna KTN w składzie: Kawecki, Łuszczyński, Worosz wygrała bieg rozstawny ${ }^{74}$.

Walne zgromadzenie członków KTN odbyło się 12 grudnia 1913 roku. Miesiąc później, 7 stycznia 1914 roku, we Lwowie i Sławsku na zaproszenie KTN zjawił się Sepp Obereder z Grazu, a 21 stycznia 1914 roku Georg Bilgeri, którzy przeprowadzili intensywne szkolenia narciarskie.

Pierwsze po wojnie walne zgromadzenie KTN odbyło się w październiku 1919 roku w mieszkaniu Kazimierza Lubienieckiego ${ }^{75}$. W trakcie tego spotkania funkcję prezesa wydziału KTN powierzono Klemensiewiczowi ${ }^{76}$, a funkcję prezesa Komisji Rewizyjnej - Stanisławowi Płońskiemu ${ }^{77}$. Za najważniejsze zadanie na najbliższy czas uznano odbudowę schroniska w Sławsku. Przedstawiciele KTN wzięli też wówczas udział w pierwszym po wojnie Zjeździe Delegatów Towarzystw Turystycznych, który odbył się w dniach 11-12 października 1919 roku we Lwowie. W trakcie obrad Zjazdu rozpoczęły się działania zmierzające do utworzenia Polskiego Związku Narciarskiego. Następnie 26 grudnia 1919 roku w Zakopanem odbyło się zebranie, podczas którego zawiązano Polski Związek Narciarski. Stowarzyszenie to zawiązały: Karpackie Towarzystwo Narciarzy (delegaci: Klemensiewicz, Rittersschild) ze Lwowa, Sekcja Narciarska Towarzystwa Tatrzańskiego z Zakopanego, Tatrzańskie Towarzystwo Narciarzy z Krakowa, Sekcja Narciarska Akademickiego Związku Sportowego z Krakowa oraz Wintersportklub z Bielska.

Kolejne walne zgromadzenie KTN odbyło się 21 grudnia 1921 roku we Lwowie. Zebranie otworzył prezes Klemensiewicz, przedstawiając swoją opinię dotyczącą stanu Towarzystwa. Zauważył spadek zainteresowania działalnością wśród

73 Zawody narciarskie w Stawsku, „Nasza Turystyka” 1, 1913, nr 3, s. 12.

74 A. Fredro-Boniecki, op. cit., s. 61.

75 XXV Sprawozdanie Wydziału KTN za czas od 1 listopada 1930 do 31 października 1931, Lwów 1931, s. 2.

76 A. Skoczylas, Narciarstwo i turystyka narciarska Zygmunta Aleksandra Klemensiewicza, [w:] Profesor doktor Zygmunt Aleksander Klemensiewicz, Gliwice 1978, s. 16.

77 Protokół walnego zgromadzenia KTN we Lwowie w dniu 21 grudnia 1921 roku, Державний архів Львівської області (ДАЛО), Справа про діяльність товариства “Карпатське товариство лижників у Львоbа, Ф. 110, On. 4, Cnp. 13, k. 29. 
młodych ludzi, a także niską frekwencję na zgromadzeniu. Sprawozdanie z działalności przedstawił Adam Lenkiewicz, podając, że w 1921 roku urządzono 12 wycieczek jednodniowych oraz jedną czterodniową przy przeciętnej frekwencji dziesięciu osób; urządzono trzy kursy, z niską frekwencją. Na dzień sprawozdania KTN liczyło zaledwie 59 członków. Wybrano nowy zarząd z Klemensiewiczem jako prezesem, pełnił on tę funkcję do końca istnienia KTN.

Akcja szkoleniowa prowadzona była przez KTN z dużą starannością. ,Spport” z dnia 14 kwietnia 1922 roku doniósł o proponowanych wycieczkach i szkoleniach: 14 kwietnia miała się odbyć trzydniowa wycieczka w Gorgany, 15 kwietnia dwudniowa do Sławska ${ }^{78}$. Prócz nich zorganizowano wycieczkę w Gorgany, rozpoczętą wyjazdem ze Lwowa koleją do Broszniowa i kolejką do Osmołody, później już na nartach na Płyśce (1150 m n.p.m.) z noclegiem w schronisku, następnie Grofa (1752 m n.p.m.) i zjazd do Osmołody, skąd następnego dnia miało nastąpić wejście na Wysoką (1805 m n.p.m.) ${ }^{79}$.

Na przełomie lat 1922 i 1923 KTN zorganizował w Sławsku kurs jazdy na nartach dla zaawansowanych, na którym zajęcia prowadził specjalnie w tym celu sprowadzony z Budapesztu Istvan Devan. W ramach kursu, w którym udział wzięło dziesięciu zawodników KTN i dziesięciu przedstawicieli SN Czarni Lwów, prowadzono zajęcia z zakresu biegu płaskiego, zjazdu, ewolucji i skoków ${ }^{80}$.

W zorganizowanych 21 stycznia 1923 roku we Lwowie zawodach gimnazjalnych na trasie Czartowska Skała-Szkoła Przemysłowa startowało 12 zawodników; pierwsze miejsce zajął Stanisław Teisseyre, przed Stanisławem Bialikiewiczem i Janem Pająkiem. Następnie 4 lutego 1923 roku odbył się tradycyjny bieg z Trościana, w którym udział wzięło ośmiu zawodników w kategorii seniorzy I oraz jedenastu zawodników w kategorii seniorzy II; zwyciężył W. Galica z SN Pogoń Lwów, a Wacław Czerwiński z KTN był drugi. Z kolei w II Międzynarodowych Zawodach w Zakopanem, obywających się w dniach 16-18 lutego 1923 roku, należy odnotować dobry wynik Teisseyrego, który w kategorii seniorów II zajął czwarte miejsce (z czasem 1 godzina 6 minut i 42 sekundy), w skokach osiągając trzecią lokatę, co skutkowało drugim miejscem w Mistrzostwach Tatr na rok 1923.

W dniach 10-11 marca 1923 roku KTN na zlecenie PZN IV urządziło Związkowe Mistrzostwa Polski w narciarstwie w Sławsku ${ }^{81}$. Według danych z artykułu zamieszczonego w dwutygodniku „Sport” ogółem w biegach startowało 35 zawodników, w tym 26 w kategorii seniorów i 9 juniorów, a w skokach -20 zawodników, co sprawozdawca z „Przeglądu Sportowego” uznał za liczbę znaczącą. Wśród startujących w biegu było sześciu reprezentantów KTN, a wśród skoczków — pięciu. Bieg główny w obu klasach prowadził trasą o długości 18 kilometrów z Knyłyszcza (1285 m n.p.m.) przez Wełyki Wierch (1245 m n.p.m.) i Kazanowiec (905 m n.p.m.) do Sławska. Bieg juniorów do 18 lat miał zbliżoną trasę — zaczynał się

78 Z narciarstwa. Karpackie Towarzystwo Narciarzy, „Sport” 1922, nr 5, s. 76.

79 Z narciarstwa. Karpackie Towarzystwo Narciarzy, „Sport” 1922, nr 7, s. 106.

80 Okres świateczny w Stawsku, „Przegląd Sportowy” 1923, nr 2 (87), s. 8.

81 Zawody narciarskie o mistrzostwo Polski w Stawsku, „Sport” 1923, nr 44, s. 50. 
w Kazanowcu i prowadził do Sławska, ale miał długość 9 kilometrów. W biegu seniorów klasy II najlepszy był Wacław Czerwiński z KTN, a Władysław Klimkiewicz był czwarty w takiej samej kategorii w skokach, podczas gdy S. Bialikiewicz wygrał bieg w klasie młodszych. W skokach w klasie młodszych Czerwiński był drugi, a Klimkiewicz - czwarty. Skoki odbyły się na skoczni na stokach Zełenego, która została zbudowana wspólnym wysiłkiem KTN i Czarnych Lwów ${ }^{82}$.

Kolejne walne zgromadzenie KTN odbyło się 4 grudnia 1923 roku. Wśród szczegółowych informacji pojawiła się i taka, że prócz urządzonych 30 wycieczek jednodniowych w Bieszczady zorganizowano dwie kilkudniowe w Gorgany i trzy kursy dla początkujących narciarzy we Lwowie. W sprawozdaniu pojawiły się informacje o podjęciu wspólnie z SN Czarni Lwów i SN Pogoń Lwów inicjatywy budowy skoczni narciarskiej w Żelaznej Wodzie. Do realizacji projektu w tej lokalizacji jednak nie doszło w wyniku braku porozumienia z gminą Lwów. Ważne było podkreślenie, że KTN realizował podjęty program równoczesnego wspierania turystyki i sportu narciarskiego. W sprawozdaniu podano, że KTN liczy 197 członków, przy czym w 1923 roku przystąpiło 66 osób. Na wniosek radcy Lubienieckiego nadano Klemensiewiczowi godność członka honorowego KTN. Przyjęto także uchwałę o uznaniu lwowskiego dwutygodnika „Sport” organem urzędowym $\mathrm{KTN}^{83}$. We Lwowie 20 grudnia 1923 roku wydano 77 numer rzeczonego pisma, który był pierwszym numerem uznanym przez KTN jako jego urzędowy organ.

$\mathrm{Na}$ koniec tego samego roku, 31 grudnia, w Sławsku odbyły się tradycyjne zawody narciarskie zorganizowane przez KTN i SN Czarni Lwów. W biegu na 12 kilometrów zwyciężył Szczepan Witkowski, drugi był Bialikiewicz z KTN, podczas gdy Teisseyre zmylił drogę i mimo dobrego biegu nie został sklasyfikowany. Wśród 12 startujących juniorów reprezentujący KTN Jan Roehr był drugi, a Tadeusz Owiński trzeci ${ }^{84}$. W 1924 roku odbyło się kilkanaście wycieczek zorganizowanych przez KTN, jeszcze więcej urządzonych przez członków KTN prywatnie. W Sławsku odbyły się ponadto trzy kursy narciarskie. Rozpoczęto też prace ziemne nad budową skoczni narciarskiej na Zniesieniu we Lwowie ${ }^{85}$.

W dwutygodniku „Sport” z 4 marca 1924 roku Roman Loteczka w artykule omawiającym Mistrzostwa Polski w Krynicy krytykował władze Lwowa za przyczynienie się do wstrzymania rozbudowy skoczni narciarskiej na Żelazowej Wodzie, co przyczyniło się do słabej formy i odległych lokat lwowskich skoczków. Ostatecznie zrezygnowano z tej lokalizacji i w wyniku podjętych przez Czerwińskiego poszukiwań wybrano na budowę skoczni nowe miejsce — na Zniesieniu.

W dniu 1 maja 1924 roku we Lwowie odbyło się nadzwyczajne walne zgromadzenie KTN, na którym przeprowadzono zmianę statutu. Główną zmianą było wprowadzenie możliwości tworzenia sekcji, które nie będą miały osobowości prawnej. Następnie 27 listopada 1924 roku w lwowskim lokalu KTN od-

82 Narciarstwo, „Przegląd Sportowy” 1923, nr 12 (97), s. 7-8.

83 Sporty zimowe. Karpackie Towarzystwo Narciarzy we Lwowie, „Sport” 1923, nr 77, s. 451.

${ }^{84}$ Zawody narciarskie w Stawsku, „Sport” 1924, nr 79, s. 20.

85 Sprawozdanie Wydziału KTN za rok 1924/25, Lwów 1925, s. 4. 
było się walne zgromadzenie. Należy odnotować przywitanie Dudryka, który po kilkuletniej wojennej tułaczce powrócił do Lwowa. Obrady prowadził Klemensiewicz; w sprawozdaniu poinformował o przeprowadzeniu przez KTN licznych wypraw w Karpaty oraz o urządzeniu czterech kursów narciarskich dla początkujących. Podziękował także za współpracę Loteczce, który z powodu przeniesienia służbowego nie zamierzał kandydować do władz $\mathrm{KTN}^{86}$.

W 1925 roku KTN na doroczny bieg z Trościana wybrał 18 stycznia. W biegu głównym na trasie 12 kilometrów w II klasie seniorów zwyciężył Teisseyre, w III klasie seniorów Z. Krzywobłocki był drugi, a w biegu juniorów Zbigniew Jakubowski również był drugi.

W 1925 roku VI Zawody o Mistrzostwo Polski odbyły się w dniach 31 stycznia-2 lutego w Krynicy. W biegu głównym na trasie 15 kilometrów w klasie II Teisseyre był piąty, Adolf Meissner — szósty, a Bialikiewicz — dwunasty ${ }^{87}$, podczas gdy w biegu pań na 5 kilometrów wygrała Elżbieta Ziętkiewiczowa z SN TT, a J. Loteczkowa była czwarta, z kolei w biegu na 30 kilometrów A. Meissner był ósmy. Mimo że w skokach tym razem zawodnicy KTN nie byli w czołówce, to w klasyfikacji łącznej w walce o tytuł mistrza polski (bieg na 15 kilometrów i skoki) Teisseyre był dziewiąty ${ }^{88}$. W zawodach otwarcia sezonu, które odbyły się 20 grudnia 1925 roku w Zakopanem, sukces z zawodników KTN odniosła tylko Loteczkowa, która w biegu na dystansie 6 kilometrów zajęła pierwsze miejsce ${ }^{89}$. Następnie 16-17 stycznia 1926 roku odbyły się III Zawody o Mistrzostwo Zakopanego. W biegu pań w I klasie zwyciężyła Ziętkiewiczowa (z wynikiem 47 minut 53 sekundy), a w klasie II Loteczkowa (z czasem 48 minut 12 sekund) ${ }^{90}$.

Kolejną rywalizację, tym razem promujące narciarstwo zawody pod patronatem Kuriera Lwowskiego, KTN zorganizował we Lwowie 22 stycznia 1926 roku. W biegu po lwowskich ulicach na dystansie 5 kilometrów wzięło udział 30 zawodników, ukończyło go 25, a zwyciężył Z. Jakubowski z KTN. Następnie 13-14 marca 1926 roku odbyły się zorganizowane przez KTN zawody o mistrzostwo Lwowa. W skokach narciarskich zwyciężył Szwed Wilhelm Stolpe, startujący w barwach SN PTT, a czwarte miejsce zajął reprezentant KTN - Teisseyre. Zawody w skokach zrealizowano na skoczni na Zniesieniu, gdzie wykorzystano naturalne ułożenie stoku o pięćdziesięciometrowej wysokości i w styczniu, przed zawodami, wykonano drewnianą konstrukcję progu. Budowę skoczni zakończono w 1926 roku. Ustawiono widoczny na zachowanych zdjęciach drewniany pomost i wykonano trybunę dla sędziów. Drewniane elementy skoczni były demontowane na lato, aby uniknąć zniszczenia bądź kradzieży. Zaprojektowanie tej skoczni zaproponowano kpt. Loteczce (parametry skoczni: rozbieg 72 metry, 30,5\% spadku,

86 Walne Zgromadzenie Karpackiego Towarzystwa Narciarzy, „Sport” 1924, nr 118, s. 471.

87 Zawody narciarskie o Mistrzostwo Polski w Krynicy, „Sport” 1925, nr 123, s. 35.

88 H. Szatkowski, Sport w roku 1925, [w:] Narciarstwo polskie, s. 201-202.

89 S. Fächer, Zawody narciarskie w kraju w sezonie 1925-26, [w:] Narciarstwo polskie, t. 2, Kraków 1927, s. 17.

90 Ibidem, s. 21. 
próg założony horyzontalnie, nadbudowa płaska 14 metrów [punkt martwy], zeskok: 55 metrów długości, 35\% spadu). Projektując skocznię, kpt. Loteczka liczył na długości skoków powyżej 50 metrów. Profil skoczni wraz z usytuowaniem jej w terenie, umożliwiający jej wykonanie, wykonał inż. Mieczysław Lerski, członek $\mathrm{KTN}^{91}$. Część kosztów budowy skoczni (3900 złotych) pokrył PZN, część — miasto Lwów. Niestety brak ogrodzenia wokół skoczni, mimo dużego zainteresowania zawodami wykazanego przez lwowian, spowodował, że wpływy za bilety wejściowe były nieznaczne i nie pozwalały na właściwą eksploatację skoczni.

W 1926 roku Loteczkowa zdobyła Mistrzostwo Polski (pierwszy raz rozgrywane w kategorii pań) na zawodach w Zakopanem w dniach 6-7 marca 1926 roku, osiągając na dystansie 5 kilometrów czas 29 minut i 54 sekundy i wyprzedzając następną zawodniczkę o 3 minuty i 13 sekund. Loteczkowa zajęła również pierwsze miejsce w zawodach zorganizowanych przez Koszycki Klub Sportowy w Starym Smokowcu w dniach 6-8 stycznia 1926 roku w biegu na dystansie 4 kilometrów, wyprzedzając kolejną zawodniczkę o 3 minuty i 59 sekund ${ }^{92}$.

W dniach 13-14 marca 1926 roku KTN organizował Mistrzostwa Lwowa w narciarstwie. Tylko w biegu juniorów na dystansie 14 kilometrów odnotowano wysokie miejsce reprezentanta KTN — w klasie III Krzywobłocki był trzeci (warto dodać, że w klasie juniorów na dystansie 7 kilometrów zwyciężył B. Czech), podczas gdy Loteczkowa zwyciężyła w biegu pań na dystansie 5 kilometrów. Lepiej reprezentanci KTN wypadli w skokach - w klasie I Teisseyre był czwarty, w klasie II zwyciężył Roehr, a Czerwiński był trzeci ${ }^{93}$.

Talent Loteczkowej rozwinął się w 1927 roku, kiedy to zdobyła mistrzostwo Austrii, Czechosłowacji, Francji i Polski, stając się najlepszą narciarką w Europie. Rok 1927 rozpoczęła, zajmując z czasem 45 minut 52 sekundy drugie miejsce (pierwsze w klasie I) w biegu na dystansie 8 kilometrów w zawodach o mistrzostwo Zakopanego, które odbyły się w dniach 8-9 stycznia ${ }^{94}$. Jej talent dostrzeżono — na okładce „Przeglądu Sportowego” z 29 stycznia 1927 roku pojawiło się zdjęcie tej znakomitej biegaczki ${ }^{95}$.

Rocznicowy rok był pełen pracy. Przebudowano skocznię narciarską na Zniesieniu, aby uzyskać lepsze wyprofilowanie. W zawodach w skokach, które odbyły się 16 stycznia 1927 roku w bardzo złych warunkach śniegowych, zwycięzca Czech narodowości niemieckiej Franciszek Wende - osiągnął odległości 36 i 38 metrów i notę 18,83 pkt, drugi był B. Czech. Najdłuższy skok na odległość 42 metry, oddany poza konkursem w czasie treningu 15 stycznia, wykonał Wende, który w owym czasie należał do światowej czołówki skoczków. Zawody zgromadziły 5 tysięcy widzów, a udział wzięło w nich 20 skoczków. W kombinacji zwyciężył

91 Kilka słów o skoczni na Zniesieniu. Kpt. Roman Loteczka, „Sport” 1927, nr 201, s. 25-27.

92 S. Fächer, Zawody narciarskie w kraju, [w:] Narciarstwo polskie, t. 2, s. 17, 21, 26, 31, 40, 48.

93 Sprawozdanie Wydziału Karpackiego Towarzystwa we Lwowie za rok 1925/26, Lwów 1926, s. 3.

94 M. Świerz, Mistrzostwa narciarskie Zakopanego, „Przegląd Sportowy” 1927, nr 3 (296), s. 3.

95 Ilustracja: Loteczkowa. Stynna narciarka lwowska p. Loteczkowa startuje w biegu pań na 8 km o tytuł mistrzyni Zakopanego, „Przegląd Sportowy” 1927, nr 4 (297), s. 1. 
B. Czech, drugie miejsce zajął Józef Lankosz, obaj z SN TT (Lankosz niebawem przeniósł się do Lwowa i KTN), a w klasie III Jakubowski był drugi ${ }^{96}$.

Okolicznościowe zawody z okazji 20. rocznicy powstania KTN odbyły się 22-23 stycznia 1927 roku. Główne uroczystości miały miejsce 23 stycznia podczas uroczystego bankietu w salach Hotelu Krakowskiego. Bankiet poprzedzony był odczytem Kordysa na temat początków narciarstwa we Lwowie, wygłoszonym w Sali Sesyjnej „Wieku Nowego”. Rocznicę miały uświetnić zawody reprezentacji wojskowych Czechosłowacja-Rumunia-Polska oraz zawody o mistrzostwo Polski kobiet. Niestety goście odwołali swój przyjazd, a na bieg o mistrzostwo kobiet zgłosiły się dwie narciarki i w związku z tym zawody nie doszły do skutku. W zamian zorganizowano Zawody Jubileuszowe z udziałem lwowskich i zakopiańskich zawodników, którzy przybyli do Lwowa ${ }^{97}$. Bieg na 18 kilometrów, który odbył się 22 stycznia 1927 roku, zgromadził 36 zawodników w kategorii seniorów. Do mety dotarło 17, a wygrał B. Czech z czasem 1 godzina 35 minut 18 sekund. W biegu narciarskim na dystansie 8 kilometrów startowało 8 juniorów. Niejaki Heppe (imię nieznane) zajął miejsce czwarte (z czasem 50 minut), a Teisseyre II — piąte (z czasem 51 minut 35 sekund). Następnie 23 stycznia odbył się konkurs skoków.

O zainteresowaniu lwowian zawodami świadczy fakt, że przybyli na trybuny zawodów w liczbie ponad 5 tysięcy (według tygodnika „Sport” z dnia 28 stycznia 1927 roku - 8 tysięcy). Zwyciężył Lankosz, który w najdłuższym ze swoich trzech skoków osiągnął 29 metry, zwyciężył także w kombinacji. Trzecie miejsce w skokach zajął Teisseyre z KTN ${ }^{98}$ ze skokami o długości 19, 22 i 22,5 metra i notą 15,02 pkt. Z kolei Loteczkowa 13 lutego zdobyła mistrzostwo Francji, pokonując w biegu o długości 5 kilometrów 17 narciarek $^{99}$, a 19 lutego na trasie 8 kilometrów w Zakopanem zwyciężyła w biegu pań o mistrzostwo Polski z czasem 42 minuty i 26 sekund, pokonując Ziętkiewiczową o 4 minuty i 41 sekund ${ }^{100}$. Kontynuując pasmo sukcesów, Loteczkowa w zawodach w dniach 26-27 lutego 1927 roku w Westerowie wygrała bieg na trasie 3 kilometrów, pokonując 19 zawodniczek i zostając Mistrzynią Tatr Południowych ${ }^{101}$. W związku z tym „Przegląd Sportowy" w wydaniu z dnia 9 kwietnia 1927 roku na pierwszej stronie zaprezentował zdjęcie Loteczkowej z podpisem, w którym stawiał ją na równi z Haliną Konopacką — dyskobolką, rekordzistką świata, najbardziej w tym czasie znaną Polką uprawiającą sport. W tym samym numerze pismo poinformowało, że

96 Wielkie dni narciarskie we Lwowie, „Przegląd Sportowy” 1927, nr 3 (296), s. 6; Sprawozdanie Wydziału Karpackiego Towarzystwa Narciarzy we Lwowie za rok administracyjny 1926/27, Lwów 1927, s. 39.

97 Odrodzenie narciarstwa we Lwowie. Zawody jubileuszowe Karpackiego Tow. Narc., „Przegląd Sportowy” 1927, nr 4 (297), s. 6.

98 Ibidem.

99 Sprawozdanie Wydzialu Karpackiego Towarzystwa Narciarzy we Lwowie za rok administracyjny 1926/27, Lwów 1927, s. 40.

100 Wielkie dni narciarskie w Zakopanem. Zawody Międzynarodowe o Mistrzostwo Polski i Armii, „Przegląd Sportowy” 1927, nr 8 (301), s. 2.

101 Mistrzostwa Narciarskie Tatr Południowych, „Przegląd Sportowy” 1927, nr 10 (303), s. 3. 
25 marca 1927 roku Loteczkowa wygrała bieg o mistrzostwo Austrii w miejscowości Rax ${ }^{102}$. Następnie w „Przeglądzie Sportowym” z dnia 7 stycznia 1928 roku ukazała się obszerna rozmowa, zatytułowana Wywiad z Janina Loteczkowa, kto wie, czy nie najlepsza narciarka świata ${ }^{103}$. Parę tygodni później, 27 stycznia 1928 roku, w biegu na 7 kilometrów w Chamonix Loteczkowa zwyciężyła, pokonując następną zawodniczkę o około 5 minut i zdobywając tytuł mistrzyni Francji104. „Przegląd Sportowy” z dnia 11 lutego1928 roku poinformował o wynikach konkursu na najlepszego polskiego sportowca w roku 1927 roku - wygrała go Konopacka, podczas gdy Loteczkowa zajęła siódme miejsce, nieznacznie ustępując B. Czechowi ${ }^{105}$.

W drugiej Zimowej Olimpiadzie w St. Moritz, która odbyła się w dniach 11-19 lutego 1928 roku wśród 12 zawodników reprezentujących Polskę był jeden przedstawiciel KTN - Franciszek Kawa, który w biegu na 50 kilometrów w niezwykle trudnych warunkach zajął 27. miejsce na 41 startujących i 30 sklasyfikowanych ${ }^{106}$. W tym samym miesiącu, 26 lutego 1928 roku, Loteczkowa startowała w Davos. Mimo odniesionej w trakcie biegu już na 2. kilometrze kontuzji (naderwanie ścięgna i mięśnia w prawej nodze) w rywalizacji na dystansie 10 kilometrów przy różnicy poziomów 1400 metrów, w którym startowały 72 zawodniczki, zajęła drugie miejsce ${ }^{107}$.

Jeszcze w tym samym roku, 27 marca 1928 roku, sformalizowano istnienie ponad trzydziestoosobowej Sekcji Kajakowej, na której czele w nieco późniejszym okresie stanęli Kazimierz Lubieniecki oraz Adam Zieliński. Sekcja ta w 1937 roku, mając 57 czynnych członków i wyposażona w 15 własnych kajaków, stała się Sekcją Polskiego Związku Kajakowego ${ }^{108}$.

Na początku 1929 roku Loteczkowa doznała kontuzji podczas treningu na nartach w okolicach Złoczowa. Był to na tyle skomplikowany uraz, że sezon 1929 roku uznano dla niej za stracony.

W tymże roku Towarzystwo urządziło konkurs na nową odznakę, w którym wzięło udział 50 autorów ${ }^{109}$. Wygrał go Michał Klimkiewicz z Warszawy, za co otrzymał nagrodę w wysokości 100 złotych. Odznaki były sprzedawane wyłącznie członkom KTN, zobowiązywali się oni do niewymieniania się z kolekcjonerami

102 Narciarze polscy mistrzami Austrii, „Przegląd Sportowy” 1927, nr 14 (307), s. 5.

103 Wywiad z Janina Loteczkowa, kto wie, czy nie najlepsza narciarka świata, „Przegląd Sportowy" 1928, nr 1 (346), s. 2.

104 Loteczkowa mistrzynią Francji, „Przegląd Sportowy” 1928, nr 5 (350), s. 2.

105 Rozstrzygnięcie dorocznego konkursu Przeglądu Sportowego, „Przegląd Sportowy” 1928, nr 6 (351), s. 3.

106 S. Faecher, II Olimpiada Zimowa w St. Moritz 11-19.II.1928, [w:] Narciarstwo polskie, t. 3, Kraków 1929, s. 52.

107 Ostatnie nowiny zagraniczne, ,Przegląd Sportowy” 1928, nr 10 (355), s. 2.

108 Sprawozdanie Wydziału KTN za rok 1936/7, Lwów 1937, s. 10.

109 XXXIII Sprawozdanie KTN za czas od 1 listopada 1928 do 31 października 1929, Lwów 1929, s. 15. 
w celu zachowania ich dla członków, a także do nieużywania ich po wystąpieniu z Towarzystwa. Rok 1929 Towarzystwo kończyło z 267 członkami.

Latem 1930 roku podjęto decyzję o likwidacji skoczni na Zniesieniu z powodu kłopotów finansowych wynikających z jej utrzymania. Po obniżce formy Lankosza, odejściu Kawy i problemach z formą po kontuzji Loteczkowej zawodnicy KTN nie reprezentowali już najwyższej krajowej klasy. Mimo tego 22 i 23 lutego 1930 roku reprezentacja Lwowa z zawodnikami KTN (Zbigniew Jakubowski, Jan Szczepanowski i Józef Lankosz) wzięła udział w zawodach na Zakarpaciu w miejscowości Wołowiec. Pierwszego dnia w biegu na trasie o długości 13 kilometrów Jakubowski był drugi, a Szczepanowski czwarty, na drugi dzień na trasie o długości 18 kilometrów Lankosz był piąty ${ }^{110}$.

W grudniu 1930 roku we Lwowie odbyło się otwarcie sezonu narciarskiego. $\mathrm{Na}$ Pohulance przeprowadzono bieg narciarski z udziałem 20 zawodników. Seniorzy startowali na dystansie 10 kilometrów — Zdzisław Ziółkowski z KTN był szósty, a w kategorii juniorów na dystansie 5 kilometrów Lesław Chlipalski zakończył bieg jako drugi ${ }^{111}$.

W pierwszych dniach stycznia 1931 roku narciarze polscy, a wśród nich Lankosz, wybrali się na zawody do Smokowca. W skokach Lankosz zdobył drugie miejsce, w biegu do kombinacji był czwarty i czwarty w kombinacji, a także dziewiąty w biegu na 18 kilometrów ${ }^{112}$. Loteczkowa, po prawie dwóch latach przerwy spowodowanej kontuzją, przepracowała intensywnie jesień 1930 roku i w styczniu 1931 roku pojawiła się w Zakopanem, gdzie rozpoczęła trening narciarskich, chcąc powrócić na trasy narciarskich zawodów.

Na początku kolejnego roku, 18 stycznia 1931 roku, we Lwowie SN Czarni zorganizowała bieg drużynowy o niezwykłych zasadach: każdą drużynę reprezentowało czterech narciarzy, a czas osiągnięty przez drużynę wynikał z sumy czasów reprezentantów oraz różnicy czasu między pierwszym a ostatnim z nich. Wygrała drużyna KTN w składzie: Jakubowski, S. Teisseyre, Andrzej Teisseyre i Chlipalski ${ }^{113}$. Następnie 1-2 lutego 1931 roku w Sławsku odbyły się zawody o mistrzostwo lwowskiego okręgu narciarskiego zorganizowane przez KTN. W biegu seniorów na dystansie 15,5 kilometra startowało 22 zawodników; zwyciężył Jakubowski, A. Teisseyre był szósty, w biegu juniorów na dystansie 12 kilometrów Chlipalski był drugi, podczas gdy w skokach do kombinacji w klasie seniorów wygrał Szczepanowski, A. Teiseyre był trzeci, a Jakubowski czwarty. Pierwsze miejsce w kombinacji zdobył, zarazem zostając mistrzem okręgu w kombinacji, Jakubowski ${ }^{114}$. Z kolei w biegu zjazdowym z Trościana zorganizowanym przez SN Czarni Lwów 31 grudnia 1931 roku zawodnicy KTN wypadli znakomicie: Szcze-

110 Narciarze lwowscy w Czechach, „Przegląd Sportowy” 1930, nr 18 (507), s. 5.

111 Narciarze lwowscy na starcie, „Przegląd Sportowy” 1930, nr 103 (592), s. 5.

112 J. Lankosz, Narciarze polscy w Smokowcu, „Przegląd Sportowy” 1931, nr 4 (597), s. 4.

113 Bieg drużynowy narciarzy lwowskich, „Przegląd Sportowy” 1931, nr 6 (599), s. 4.

114 Jakubowski i Marusarz zwyciężaja w Stawsku i Truskawcu, „Przegląd Sportowy” 1931, nr 15 (608), s. 4. 
panowski zajął pierwsze miejsce, Jakubowski — drugie, a Jerzy Solak — piąte. Na koniec 1931 roku KTN liczyło 362 członków.

W zorganizowanym 1 stycznia 1932 roku w Sławsku konkursie skoków Jakubowski był pierwszy, a Szczepanowski drugi. W dodatku na okres 1931/1932 Wydział Towarzystwa pozyskał dwie stacje noclegowe oferujące noclegi z pościelą i pełne wyżywienie. Jedna z nich mieściła się w Zarządzie Dóbr Jabłonki w gminie Baligród (zarządca Gostomski), druga w miejscowości Sokole nad Sanem (u Brandysów ${ }^{115}$. Ten kierunek pozyskiwania miejsc noclegowych świadczył o zamiarach rozpoczęcia eksploracji, cieszących się dotychczas mniejszą popularnością, terenów narciarskich na zachód od Sławska.

W pierwszych dniach lutego 1932 roku reprezentacja lwowskich narciarzy wzięła udział w zawodach w Wołowcu na Zakarpaciu. W jej skład weszli zawodnicy KTN: A. Teisseyre oraz Jakubowski. Bieg na dystansie 20 kilometrów z obciążeniem 5 kilogramów zakończył się zwycięstwem reprezentacji Lwowskiego Okręgowego Związku Narciarskiego ${ }^{116}$. Następnie w dniach 13-14 lutego 1932 roku w Brzuchowicach odbyły się mistrzostwa Lwowa w narciarstwie; 13 lutego na starcie biegu stanęło 70 zawodników, w tym 41 seniorów, 19 juniorów i 10 pań, reprezentujący takie kluby, jak: Karpackie Towarzystwo Narciarzy, Przemyskie T.N., Lechia, Czarni Lwów, AZS, warszawski AZS i zakopiański Sokół. Bieg na trasie o długości 16 kilometrów wygrał Jakubowski, A. Teisseyre był trzeci, a w biegu pań na dystansie 6 kilometrów Maria Kostecka zajęła czwarte miejsce. Z kolei 14 lutego odbył się konkurs skoków na nowej skoczni na Pohulance we Lwowie. Pierwsze miejsce w skokach zajął Lankosz (najdłuższy skok o długości 18 metrów), drugie - Szczepanowski, trzecie - A. Teisseyre. Najdłuższy oddany skok o długości 22 metrów należał do startującego poza konkursem trenera norweskiego Peera Klykkena. Mistrzem Lwowa w kombinacji został A. Teisseyre; Jakubowski zajął drugie miejsce ${ }^{117}$.

Na początku lat trzydziestych KTN jako relatywnie niewielkie stowarzyszenie tracił znaczenie i pozycję, jakie miał w kreowaniu narciarstwa sportowego i turystycznego w początkowym okresie ich powstawania na ziemiach polskich. Czasami jego zawodnicy wciąż jednak uzyskiwali znaczące wyniki podczas zawodów sportowych. Na przykład 5 lutego 1932 roku Lankosz w mistrzostwach Polski AZS w Wiśle w biegu do kombinacji, w którym startowało 20 zawodników, zajął pierwsze miejsce ${ }^{118}$. Następnego dnia odbył się konkurs skoków do kombinacji, który również wygrał Lankosz, zostając mistrzem akademickim Polski ${ }^{119}$. Mając na uwadze te zmiany, działacze KTN rozpoczęli w 1932 roku rozmowy z Polskim Towarzystwem Tatrzańskim o wstąpieniu KTN do PTT i stworzeniu

115 XXVI Sprawozdanie KTN za czas 1 grudnia 1931 do 30 listopada 1932, Lwów 1932, s. 18.

116 Na śniegach Wolowca odnieśli lwowianie piękny sukces, „Przegląd Sportowy” 1932, nr 13 (710), s. 4.

117 Teisseyre mistrzem narciarskim Lwowa, „Przegląd Sportowy” 1932, nr 14 (711), s. 2.

118 Telefonem z kraju. Wista 5.2 - Tel. wt., „Przegląd Sportowy” 1933, nr 11 (812), s. 2.

119 Z różnych dziedzin, „Przegląd Sportowy” 1933, nr 12 (813), s. 2. 
nowego oddziału we Lwowie. Na zebraniu ZG PTT 4 grudnia 1932 roku ustalono, że PTT nie jest zainteresowane powstaniem we Lwowie drugiego oddziału. KTN zaproponowano zatem wstąpienie do istniejącego Oddziału PTT we Lwowie, gdzie stworzyłoby Sekcję Narciarską pod nazwą KTN z dużym zakresem samodzielności w gospodarowaniu wniesionym majątkiem (schronisko w Sławsku). Jednocześnie zwrócono się do Oddziału PTT we Lwowie o delegowanie przedstawicieli oddziału do komisji, której zadaniem byłoby przygotowanie porozumienia. Do połączenia jednak nie doszło ${ }^{120}$. Na koniec 1932 roku w KTN było 350 członków.

W dniach 2-4 lutego 1934 roku w Rabce odbyły się narciarskie akademickie mistrzostwa Polski: 3 lutego odbył się bieg otwarty i do kombinacji na 16 kilometrów panów - A. Teisseyre zajął drugie miejsce, Lankosz siódme w klasyfikacji do kombinacji, a w konkursie skoków do kombinacji Lankosz był pierwszy, a A. Teisseyre drugi ${ }^{121}$. Pod koniec lutego 1934 roku w Wołowcu odbyły się tradycyjne zawody z udziałem lwowskich i słowackich narciarzy. W biegu drużynowym na dystansie $3 \times 10$ kilometrów zwyciężyła sztafeta Czarnych Lwów, sztafeta KTN była trzecia, a indywidualnie A. Teisseyre trzeci ${ }^{122}$.

W latach trzydziestych polskie towarzystwa turystyczne, przy silnym poparciu sfer rządowych, rozpoczęły ekspansję na tereny Czarnohory i dalej na wschód, aż po Czywczyn. W wyniku tych działań powstało tam wiele schronisk turystycznych PTT, Akademickiego Związku Sportowego, Towarzystwa Przyjaciół Huculszczyzny, Związku Harcerstwa Polskiego, Ligi Popierania Turystyki, Towarzystwa Krzewienia Narciarstwa, a także schronisko Karpackiego Towarzystwa Narciarzy na południowym stoku Wielkiej Maryszewskiej (na wysokości około 1370 m n.p.m.).

Dokumentacja schroniska KTN powstała zimą 1933/1934, a jej autorami byli członkowie KTN: inż. Karol Kocimski i inż. Lech Neyman. Elewacja zewnętrzna została zaprojektowana przez inż. architekta Tadeusza Brzozę. W początku maja 1934 roku Klemensiewicz we współpracy z inż. Józefem Dobieckim wybrał i zakupił dwumorgową (około 1,12 ha) parcelę położoną na południowych stokach Wielkiej Maryszewskiej. Do końca sezonu budowlanego w 1934 roku wybudowano mury fundamentów i przyziemia, a także dwupokojowy budynek gospodarczy (warsztat stolarski i mieszkania stróża). W lutym 1936 roku można było już korzystać z noclegów. W 1936 roku KTN wydzierżawiła obiekt inżynierowi leśnictwa Witoldowi Tyskiemu, który wraz z żoną Zofią i córką Joanną gospodarowali w nim do wybuchu wojny. W sezonie 1936/1937 w schronisku udzielono ponad 3 tysięcy noclegów. Poświęcenie schroniska odbyło się 24 stycznia 1937 roku i było częścią uroczystości związanych z obchodami trzydziestolecia KTN. Schronisko otrzymało wówczas imię Zygmunta Klemensiewicza; święcił je dominikanin, ojciec

120 Odpis protokołu posiedzenia ZG PTT z dnia 4 grudnia 1932 roku, Posiedzenia ZG PTT, CATG, sygn. 2.02.01.

121 Lankosz mistrzem akademików po trzydniowej batalii narciarskiej w Rabce, „Przegląd Sportowy" 1934, nr 12 (916), s. 5.

122 Brawo narciarze Lwowa, „Przegląd Sportowy” 1934, nr 18 (922), s. 4. 
Cyryl (inż. Edmund Szlachtowski — dawny członek KTN) w obecności ministra Aleksandra Bobkowskiego oraz licznych przedstawicieli organizacji turystycznych i społecznych ${ }^{123}$.

Schroniska w Sławsku i na Maryszewskiej to obiekty o najważniejszym dla KTN znaczeniu. Okresowo Koło posiadało również inne obiekty, już nie tak znane, lecz jeden z nich był niezwykle interesujący. Było to schronisko w Berehach Górnych, będące własnością członka KTN, Władysława Serwatowskiego, właściciela folwarku w Berehach Górnych. KTN nie ponosiło kosztów jego utrzymania. Całkowicie drewniane, kryte strzechą, miało dziesięć miejsc noclegowych i oferowało pełne wyżywienie ${ }^{124}$. Należy także odnotować fakt wynajmowania przez KTN w okresie po I wojnie światowej (wspólnie z PTT) pensjonatu Trościan w Sławsku (budynek istniał jeszcze w maju 1995 roku) ${ }^{125}$.

Wracając do osiągnięć KTN, należy zacząć od tego, że w Rabce 2 lutego 1935 roku w biegu o mistrzostwo akademickie Polski na dystansie 16 kilometrów Lankosz był trzeci, a A. Teisseyre piąty (był to także bieg do kombinacji). W konkursie skoków do kombinacji Lankosz był pierwszy i zdobył tytuł akademickiego mistrza Polski na rok $1935^{126}$. Niewiele ponad tydzień później, 10 lutego 1935 roku, odbyły się mistrzostwa narciarskie Lwowa połączone z otwarciem skoczni w Brzuchowicach. Otwarcie skoczni zgromadziło 4 tysiące widzów, a otworzył ją wojewoda lwowski Władysław Belina Prażmowski. Część sportowa rozpoczęła się od skoków do biegu złożonego o mistrzostwo okręgu lwowskiego. Mistrzem Lwowa został Lankosz, drugie miejsce zajął L. Urbański (także zawodnik KTN). W otwartym konkursie skoków zwyciężył Andrzej Marusarz (40,5 i 41,5 metra), drugi był Izydor Łuszczek (45 metrów — rekord skoczni - i 34,5 metra) a trzeci był Lankosz ( 38 i 31,5 metra) ${ }^{127}$. Towarzystwo w tym okresie zanotowało spadek liczebności z 350 członków na koniec 1931 roku do 170 osób w 1935 i ponowny wzrost do $210 \mathrm{w}$ połowie 1937 roku.

W roku 1937 KTN wydał album poświęcony Huculszczyźnie pod tytułem Czarnohora ze zdjęciami autorstwa między innymi Klemensiewicza, Romana Puchalskiego, Tadeusza Olszanieckiego oraz A. Teisseyre.

W roku następnym, 16 listopada 1938 roku, Starostwo Grodzkie we Lwowie, uzupełniając swoje zasoby informacji o stowarzyszeniu, zwróciło się do Komisariatu X Policji we Lwowie z odpisem do KTN z prośbą o wypełnienie ankiety. W odpowiedzi na wystąpienie KTN przedstawiło aktualny skład zarządu, prawdopodobnie ostatni zapisany w historii tego stowarzyszenia. I tak: prezes - Zygmunt Klemensiewicz, wiceprezes - Stanisław Lubieniecki, sekretarz — Tadeusz Rogala, skarbnik - Janina Ihnatowiczowa, członkowie: Celina Dębska, Maria

123 Sprawozdanie Wydziału KTN za rok 1936/7, Lwów 1937, s. 4-5.

124 Schroniska w Beskidzie Niskim i Bieszczadach, CATG, sygn. 15.02.09.

125 J. Kapłon, Sprawozdanie z wizji lokalnej w Stawsku w maju 1995 roku, maszynopis w posiadaniu autora.

126 Na śniegu Rabki, „Przegląd Sportowy” 1935, nr 11 (1019), s. 5.

127 O mistrzostwo narciarskie Lwowa i Wilna, „Przegląd Sportowy” 1935, nr 13 (1021), s. 4. 
Kuczyńska, Andrzej Progulski, Zbigniew Kończacki, jednocześnie informując, że został on ustalony podczas walnego zgromadzenia 9 czerwca 1938 roku. Było to z pewnością ostatnie walne zgromadzenie $\mathrm{KTN}^{128}$.

Na fali odwilży październikowej doszło do próby reaktywacji Towarzystwa. Świadczą o tym dokumenty przekazane przez córkę Klemensiewicza, Annę Skoczylas, do Centralnego Archiwum Turystyki Górskiej PTTK w Krakowie. W 1958 roku ci członkowie KTN, którzy w wyniku zmiany granic po wojnie opuścili Lwów i Kresy Wschodnie, a także ci, którzy mieszkali na terenach pozostałych w powojennych granicach Polski, postanowili reaktywować Karpackie Towarzystwo Narciarzy. Niestety podjęte starania zakończyły się niepowodzeniem.

Na koniec należy podkreślić, że początki istnienia KTN to równomierny rozwój narciarstwa sportowego i turystycznego. Apogeum kierunku sportowego to sukcesy Loteczkowej. Późniejszy czas to natomiast dominacja kierunku sportowego przez zawodników z Zakopanego. Mimo że ciągle w szeregach KTN znajdowali się narciarze sportowcy, Koło główny kierunek swojej działalności widziało w rozwoju turystyki narciarskiej. Tacy zawodnicy, jak F. Kawa, S. Teisseyre, J. Roehr, czy w późniejszym okresie J. Lankosz, zajmowali podczas zawodów na szczeblu krajowym miejsca w czołówce, stanowiąc jej zaplecze oraz wygrywając zawody na szczeblu lokalnym lub (Lankosz) w konkurencjach akademickich.

Mimo ambicji sportowych, co było naturalnym biegiem rzeczy wobec upływu lat, większość członków KTN mogła już tylko uprawiać turystykę narciarską, młodsi - pozbawieni takich warunków treningowych jak mieszkańcy Zakopanego - nie mogli osiągać takich wyników jak oni. Szkolenia narciarzy, wyprawy turystyczne, troska o rozwój turystyki górskiej były kierunkami, które uznawano za dominujące w dalszym funkcjonowaniu Towarzystwa.

\section{Bibliografia}

\section{Literatura}

Bobkowski A., Tatrzańskie Towarzystwo Narciarzy w Krakowie, [w:] Onarciarstwie, Kraków 1912. Dudzik P., Szatkowski W., Historia narciarstwa polskiego, [w:] 100 lat narciarstwa $w$ Polsce historia SN PTT, 1907 Zakopane, red. P. Dudzik, W. Szatkowski, Zakopane 2007.

Kapłon J., Karpackie Towarzystwo Narciarzy - zarys dziejów, „Карпати. Людина, Етнос, Цивілізація" 6, 2016.

Kapłon J., Karpackie Towarzystwo Narciarzy. Zarys dziejów, „Wierchy” 1997, nr 63.

Kapłon J., Poczatki narciarstwa polskiego. Karpackie Towarzystwo Narciarzy we Lwowie 19071939, Kraków 2018.

Kapłon J., Schroniska Karpackiego Towarzystwa Narciarzy, [w:] Materiaty z sympozjum w 120 rocznicę budowy pierwszego schroniska Towarzystwa Tatrzańskiego, Kraków 1994.

Kapłon J., Tatrzańskie Towarzystwo Narciarzy. Zarys dziejów, Kraków 2013.

128 Odpis informacji dotyczącej walnego zgromadzenia KTN, Державний архів Львівської області (ДАЛО), Справа про діяльність товариства “Карпатське товариство лижників у Львоьа, Ф. 110, Оп. 4, Cnp. 13, k. 56. 
Karpackie Towarzystwo Narciarzy, Sprawozdanie KTN za rok administracyjny 1911/12, Lwów 1912. Małaczyński M., Nartami na Chomiak i Howerlę, „Pamiętnik Towarzystwa Tatrzańskiego” 18, 1897. Narciarstwo polskie 1888-2008, red. L. Rak, E. Małolepszy, Jasło 2009.

Pręgowski Z., Dzieje narciarstwa polskiego do 1914 roku, Warszawa 1994.

„Roczniki Polskiego Związku Narciarskiego” 1. Narciarstwo polskie, red. S. Fächer et al., Kraków 1925. „Roczniki Polskiego Związku Narciarskiego” 2. Narciarstwo polskie, red. S. Fächer et al., Kraków 1927.

„Roczniki Polskiego Związku Narciarskiego” 3. Narciarstwo polskie, red. S. Fächer et al., Kraków 1929.

Skoczylas A., Narciarstwo i turystyka narciarska Zygmunta Aleksandra Klemensiewicza, [w:] Profesor doktor Zygmunt Aleksander Klemensiewicz, Gliwice 1978.

Sporty zimowe w tradycji polskiej kultury fizycznej, red. L. Rak, Częstochowa 2011.

Sprawozdanie Karpackiego Towarzystwa Narciarzy za czas od 1 listopada 1909 do 31 października 1910, Lwów 1910.

Sprawozdanie Wydzialu Karpackiego Towarzystwa Narciarzy we Lwowie za rok administracyjny 1926/27, Lwów 1927.

Sprawozdanie Wydziału Karpackiego Towarzystwa Narciarzy za rok 1935/6, Lwów 1936.

Sprawozdanie Wydziału KTN za rok 1924/25, Lwów 1925.

Sprawozdanie Wydziału KTN za rok 1936/7, Lwów 1937.

Wzorek F., Töpfer M., Sprawozdanie Zarzadu Oddziału Tow. Tatrzańskiego „Beskid” w Nowym Saczu za rok 1909, „Pamiętnik Towarzystwa Tatrzańskiego” 31, 1910.

XXXIII Sprawozdanie KTN za czas od 1 listopada 1928 do 31 października 1929, Lwów 1929.

XXV Sprawozdanie Wydziału KTN za czas od 1 listopada 1930 do 31 października 1931, Lwów 1931. XXVI Sprawozdanie KTN za czas od 1 grudnia 1931 do 30 listopada 1932, Lwów 1932.

Złota księga narciarstwa polskiego. Karpaty Wschodnie, oprac. Z. Pręgowski, Warszawa 1992.

Zaruski M., Zarys rozwoju narciarstwa i zimowej turystyki polskiej w Tatrach, „Pamiętnik Towarzystwa Tatrzańskiego" 34, 1913.

Zieliński A., [inc.] Dnia 4 grudnia 1938..., [w:] Tatry, zestawił i wstępem zaopatrzył A. Zieliński, Kraków 1938.

\section{Artykuły prasowe}

II. Karpackie Towarzystwo Narciarzy, „Nasza Turystyka” 1, 1913.

Bieg drużynowy narciarzy lwowskich, „Przegląd Sportowy” 1931, nr 6 (599).

Brawo narciarze Lwowa, „Przegląd Sportowy” 1934, nr 18 (922).

Jakubowski i Marusarz zwyciężają w Stawsku i Truskawcu, „Przegląd Sportowy” 1931, nr 15 (608).

Januszewski Z., Kronika Sportowa, „Słowo Polskie” 18.02.1908, nr 82.

Karpackie Towarzystwo Narciarzy, „Słowo Polskie” 30.01.1907, nr 51.

Karpackie Towarzystwo Narciarzy, „Nasza Turystyka” 1, 1913.

Karpackie Towarzystwo Narciarzy, „Sport” 1927, nr 200.

Kilka słów o skoczni na Zniesieniu. Kpt. Roman Loteczka, „Sport” 1927, nr 201.

Kordys R., Tatrzańskie Towarzystwo Narciarzy, „Wędrowiec” 2, 1912, nr 27.

Kordys R., Zarys rozwoju narciarstwa polskiego, „Ruch” 1910, nr 2 (92); 1910, nr 3 (93); 1910, nr 4 (94); 1910, nr 5 (95); 1910, nr 6 (96).

Lankosz J., Narciarze polscy w Smokowcu, „Przegląd Sportowy” 1931, nr 4 (597).

Lankosz mistrzem akademików po trzydniowej batalii narciarskiej w Rabce, „Przegląd Sportowy” 1934, nr 12 (916).

Loteczkowa mistrzynia Francji, „Przegląd Sportowy” 1928, nr 5 (350).

Mistrzostwa Narciarskie Tatr Poludniowych, „Przegląd Sportowy” 1927, nr 10 (303).

Na śniegach Wołowca odnieśli lwowianie piękny sukces, „Przegląd Sportowy” 1932, nr 13 (710). 
Na śniegu Rabki, „Przegląd Sportowy” 1935, nr 11 (1019).

Narciarstwo, „Przegląd Sportowy” 1923, nr 12 (97).

Narciarze lwowscy na starcie, „Przegląd Sportowy” 1930, nr 103 (592).

Narciarze lwowscy w Czechach, „Przegląd Sportowy” 1930, nr 18 (507).

Narciarze polscy mistrzami Austrii, „Przegląd Sportowy” 1927, nr 14 (307).

„Nasza Turystyka” 1, 1913, nr 1.

O mistrzostwo narciarskie Lwowa i Wilna, „Przegląd Sportowy” 1935, nr 13 (1021).

Odrodzenie narciarstwa we Lwowie. Zawody jubileuszowe Karpackiego Tow. Narc., „Przegląd Sportowy" 1927, nr 4 (297).

Okres świąteczny w Sławsku, „Przegląd Sportowy” 1923, nr 2 (87).

Ostatnie nowiny zagraniczne, „Przegląd Sportowy” 1928, nr 10 (355).

Polskie Towarzystwo Krajoznawcze we Lwowie, „Nasze Zdroje” 3, 1912, nr 9.

Rozstrzygnięcie dorocznego konkursu Przeglądu Sportowego, „Przegląd Sportowy” 1928, nr 6 (351). „ski”, Dzień narciarski w Zakopanem, „Nasz Kraj” 5, 1910, nr 93.

Schronisko narciarskie w Stawsku, „Wierchy” 1, 1923.

Sport zimowy, „Nowa Reforma” 29, 1910, nr 475.

Świerz M., Mistrzostwa narciarskie Zakopanego, „Przegląd Sportowy” 1927, nr 3 (296).

Teisseyre mistrzem narciarskim Lwowa, „Przegląd Sportowy” 1932, nr 14 (711).

Telefonem z kraju. Wisła 5.2 - Tel. wt., „Przegląd Sportowy” 1933. nr 11 (812).

Walne Zgromadzenie Karpackiego Towarzystwa Narciarzy, „Sport” 1924, nr 118.

Walne zgromadzenie Tow. Zabaw Ludu i Młodzieży, „Słowo Polskie” 7.02.1906, nr 62.

Wiadomości bieżace. Sport zimowy, „Słowo Polskie”28.01.1907, nr 47.

Wielkie dni narciarskie w Zakopanem. Zawody Międzynarodowe o Mistrzostwo Polski i Armii, „Przegląd Sportowy” 1927, nr 8 (301).

Wielkie dni narciarskie we Lwowie, „Przegląd Sportowy” 1927, nr 3 (296).

Wyścigi narciarskie w Bielsku, „Czas” 63, 1910, nr 64.

Wywiad z Janina Loteczkowa, kto wie, czy nie najlepsza narciarka świata, „Przegląd Sportowy” 1928, nr 1 (346).

Zawody narciarskie o Mistrzostwo Polski w Krynicy, „Sport” 1925, nr 123.

Zawody narciarskie w Stawsku, „Nasza Turystyka” 1, 1913, nr 3.

Zawody narciarskie o mistrzostwo Polski w Stawsku, „Sport” 1923, nr 44.

Z narciarstwa. Karpackie Towarzystwo Narciarzy, „Sport” 1922, nr 5.

Z narciarstwa. Karpackie Towarzystwo Narciarzy, „Sport” 1922, nr 7.

Z różnych dziedzin, „Przegląd Sportowy” 1933, nr 12 (813).

Z zaczątków narciarstwa we Lwowie, „Sport” 1926, nr 170.

\section{Pisma, korespondencje, rękopisy}

Januszewski Z., [b.t.], „Słowo Polskie” 6.12.1908, nr 570, Muzeum Tatrzańskie, Spuścizna po Z. Pręgowskim, z. $1908 \mathrm{r}$.

Książka pamiątkowa schroniska w Stawsku za lata 1911-1924, zbiory prywatne Alicji i Jerzego Kapłonów.

Odpis informacji dotyczącej walnego zgromadzenia KTN, Державний архів Львівської області (ДАЛО), Справа про діяльність товариства “Карпатське товариство лижників у Львоьа, Ф. 110, Оп. 4, Cnp. 13, k. 56.

Odpis protokołu posiedzenia ZG PTT z dnia 4 grudnia 1932 roku, Posiedzenia ZG PTT, Centralne Archiwum Turystyki Górskiej PTTK w Krakowie, sygn. 2.02.01.

Pismo c.k. Dyrekcji Policji we Lwowie z dnia 19 lutego 1907 roku, Державний архів Львівської області (ДАЛО), Справа про діяльність товариства “Карпатське товариство лижників у Львоьа, Ф. 110, Оп. 4, Cnp. 13, k. 2. 
Pismo KTN z dnia 9 grudnia 1909 roku do Dyrekcji c.k. Policji we Lwowie, Lwowskie starostwo grodzkie, Державний архів Львівської області (ДАЛО), Справа про діяльність товариства “Карпатське товариство лижників у Львоbа, Ф. 110, Оп. 4, Спр. 13, k. 15.

Pismo z dnia 11 lutego 1907 roku do Namiestnictwa we Lwowie, Прохання засновників товариства лижників у Львові про затвердження доданого статуту і рішення по цьому питанню, ЦДІА України, м. Львів, Ф. 146, Оп. 58, Спр. 2926.

Potwierdzenie odbioru reskryptu c.k. Namiestnictwa z dnia 3 stycznia 1911 roku w sprawie asygnaty na kwotę 5000 K., Lwowskie starostwo grodzkie, Державний архів Львівської області (ДАЛО), Справа про діяльність товариства “Карпатське товариство лижників у Львоbа, Ф. 110, Оп. 4, Cnp. 13, k. 24.

Protokół walnego zgromadzenia KTN we Lwowie w dniu 21 grudnia 1921 roku, Державний архів Львівської області (ДАЛО), Справа про діяльність товариства “Карпатське товариство лижників у Львоbа, Ф. 110, On. 4, Cnp. 13, k. 29.

Schroniska w Beskidzie Niskim i w Bieszczadach, Centralne Archiwum Turystyki Górskiej PTTK w Krakowie, sygn. 15.02.09.

„Słowo Polskie” 11.01.1909, nr 16, Muzeum Tatrzańskie, Spuścizna po Z. Pręgowskim, z. 1909 r. „Słowo Polskie” 26.01.1909, nr 42, Muzeum Tatrzańskie, Spuścizna po Z. Pręgowskim, z. 1909 r. „Słowo Polskie” 10.02.1909, nr 67, Muzeum Tatrzańskie, Spuścizna po Z. Pręgowskim, z. 1909 r. Sprawozdania KTN z wypraw turystycznych za okres 25 grudnia 1907-22 kwietnia 1911, rękopis, zbiory prywatne Alicji i Jerzego Kapłonów.

Sprawozdania Maksymiliana Dudryka z wypraw turystycznych za okres 1899 r. do 18 luty 1908 r., rękopis, zbiory prywatne Alicji i Jerzego Kapłonów.

Statut Karpackiego Towarzystwa Narciarzy, Прохання засновників товариства лижників у Львові про затвердження доданого статуту і рішення по цьому питанню ЦДІА України, м. Львів, Ф. 146, Оп. 58, Спр. 2926.

Wycinek z gazety, Archiwum Państwowe Kraków TTN 12/3, d. 205.

Zaproszenie na walne zebranie Krakowskiego Koła Karpackiego Tow. Narciarzy, Archiwum Muzeum Tatrzańskiego, sygn. AR/NO 234, k. 170. 